\title{
miRNA functions in pluripotency and
}

\section{spermatogenesis}

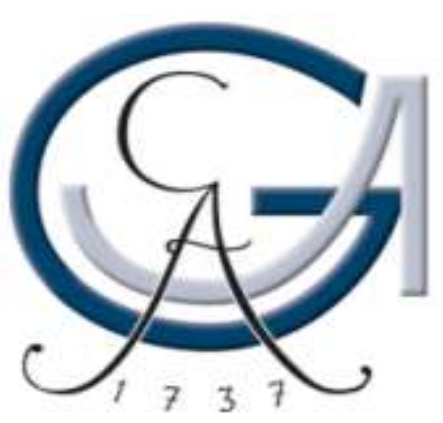

\section{DISSERTATION}

zur Erlangung des

Mathematisch-Naturwissenschaftlichen Doktorgrades

„Doctor rerum naturalium”

An der Georg-August-Universität Göttingen

vorgelegt von

Lukasz Smorag

aus Krapkowice

(Polen)

Göttingen, 2012 
D7

Referent: Prof. Dr. Dr. h.c. Wolfgang Engel

Korreferent: Prof. Dr. Sigrid Hoyer Fender

Tag der mündlichen Prüfung: 18.10.2012 
Dedicated to my parents and my wife 
Table of contents

Table of contents

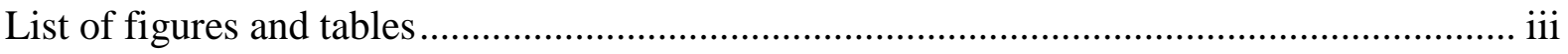

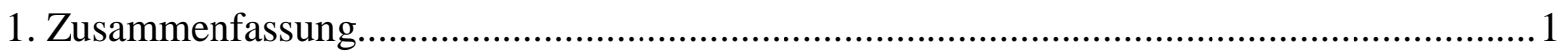

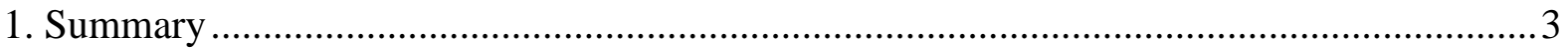

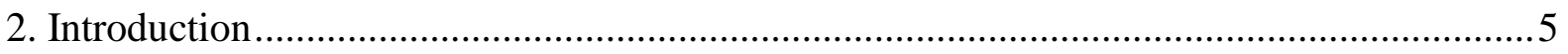

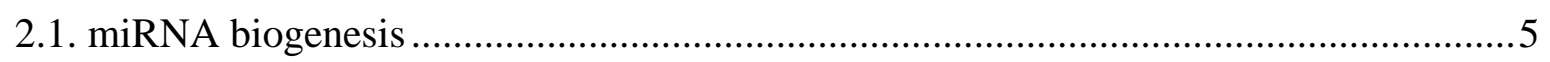

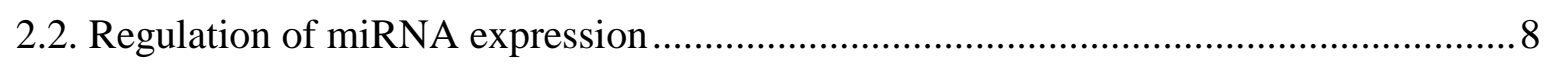

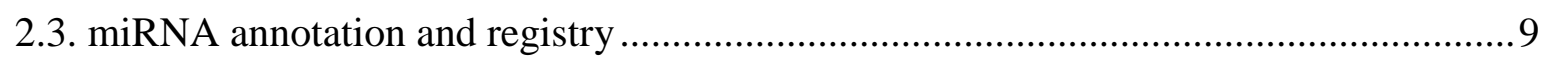

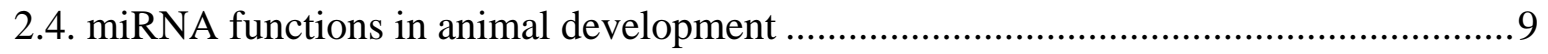

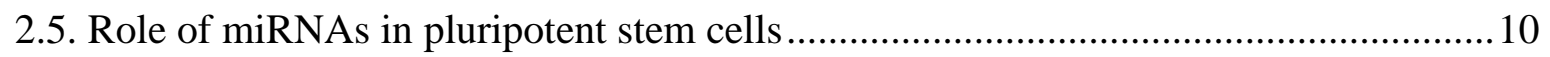

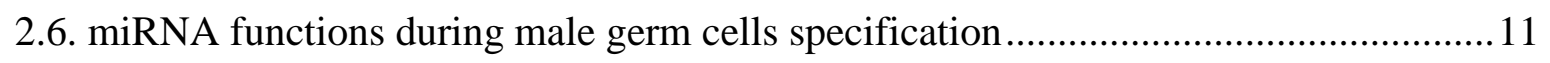

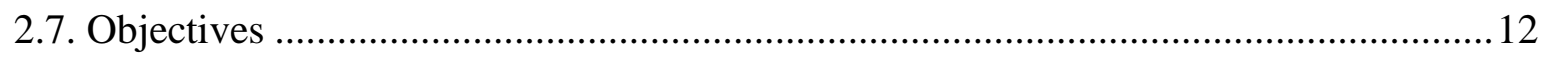

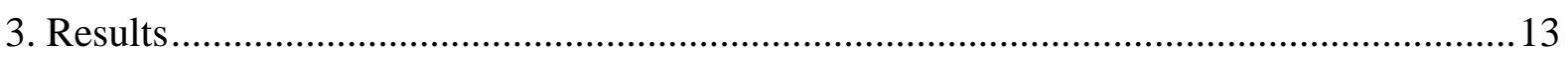

3.1 Members of the miR-290 cluster modulate in vitro differentiation of mouse embryonic stem cells.

3.2. Embryonic stem cell-related miRNAs are involved in differentiation of pluripotent cells originating from the germ line.

3.3. MicroRNA signature in various cell types of mouse spermatogenesis: Evidence for stage-specifically expressed miRNA-221, -203, and -34b-5p mediated spermatogenesis

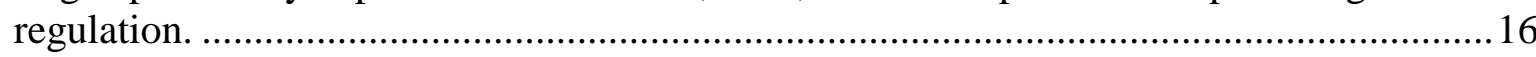

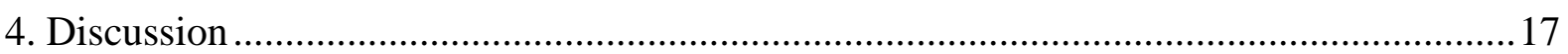

4.1 Pluripotent stem cell-specific miRNAs and their functions ........................................ 17

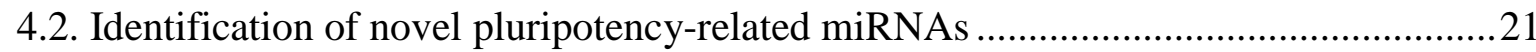

4.2.1. miRNA-135b and -363 are transcriptional targets of pluripotency-related factors 23

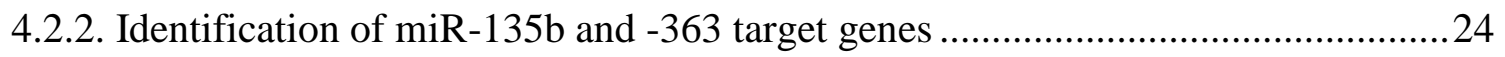

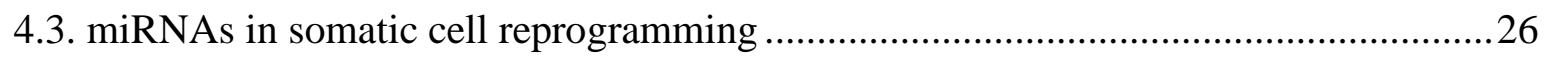

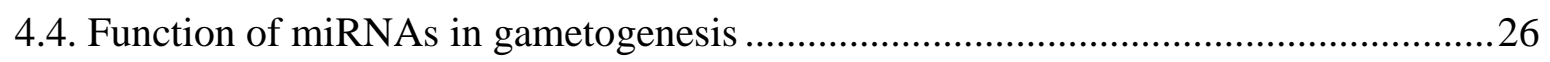

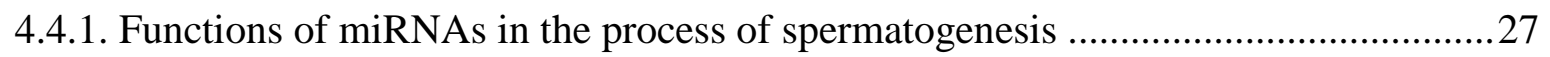

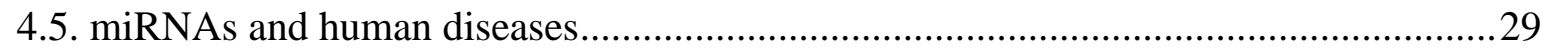

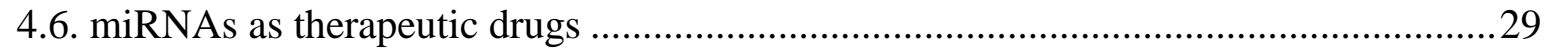

4.7. Identification and characterization of novel meiotic genes ........................................ 30

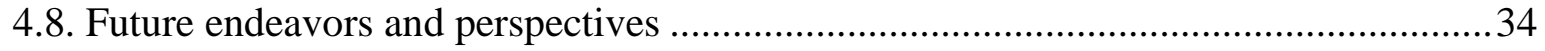

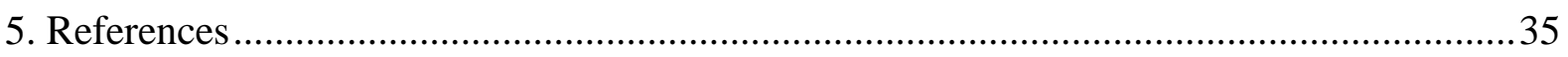

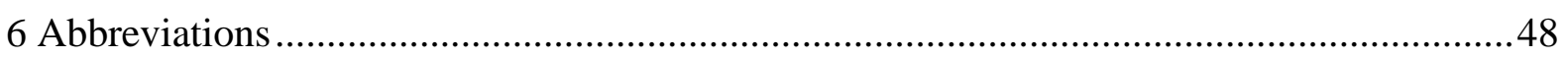




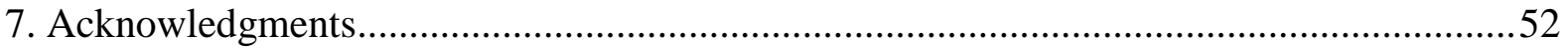

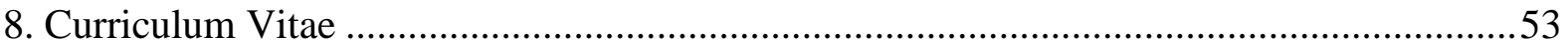

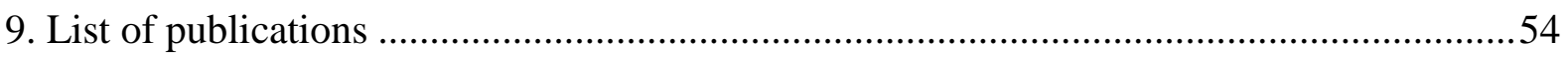

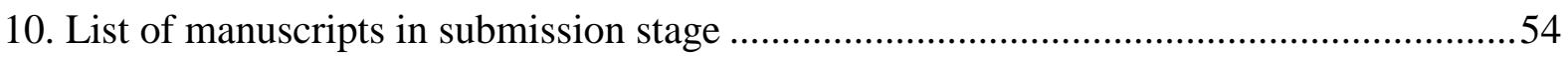




\section{List of figures and tables}

Figure 2.1. Schematic representation of canonical miRNA biosynthesis pathway 7

Figure 4.1. Cell cycle of somatic cells and ESCs

Figure 4.2. Schematic representation of the role of miRNA-290 cluster in Wnt signaling pathway .58

Figure 4.3. Identification and characterization of novel pluripotent cell-specific miRNAs.

Figure 4.4. miRNA-135b and -363 are expressed in all pluripotent cell lines 61

Figure 4.5. miRNA-135b and -363 are transcriptional targets of core pluripotency transcription factors

Figure 4.6. Identification and validation of putative target genes of miRNA-135b and -363 ....

Figure 4.7. Schematic representation of miRNAs functions in the process of mesenchymal-to-epithelial-transition. .64

Figure 4.8. Working model for the function of miRNAs during spermatogenesis .66

Figure 4.9. Transcriptome analysis of pre-meiotic (green) and meiotic (red) cells isolated from Stra8/EGFP and Sycp3/DsRed transgenic mouse testis .70

Figure 4.10. Expression analysis of Meio1-10 genes in mouse testis ..................................70

Figure 4.11. Expression analysis of novel Meio genes in different adult mouse tissues.......70

Figure 4.12. Expression analysis of novel Meio genes during mouse testis development....71

Table 4.1. List of miRNA-based therapeutics which are in clinical and pre-clinical trials .68

Table 4.2. Characterization of novel meiotic-specific genes .71 


\section{Zusammenfassung}

Nicht-kodierende RNAs (ncRNAs - non-coding RNAs) wurden lange Zeit als Artefakte angesehen. Daher war die Entdeckung von kleinen ncRNAs, insbesondere von miRNAs, überraschend. Diese können die Genexpression post-transkriptionell regulieren. Sowohl Computer-gestützte als auch experimentelle Ansätze lassen das Vorkommen von miRNAs in allen lebenden Organismen vermuten - auch in Pflanzen und Homo sapiens. Eine immer größer werdende Anzahl an Ergebnissen weisen darauf hin, dass miRNAs eine wichtige Rolle in verschiedenen Aspekten des Lebens spielen - angefangen vom einfachen Zellmetabolismus, über die Kontrolle des Zellschicksals bis hin zur Entwicklung von multizellulären Organismen. Ziel der vorliegenden Arbeit war es, die Funktion von miRNAs in pluripotenten Stammzellen und während der Spermatogenese zu untersuchen und zu verstehen.

Im ersten Teil der vorliegenden Arbeit haben wir die Rolle der Pluripotenz-spezifischen miRNA-290-Gruppe während der Differenzierung von embryonalen Stammzellen (ESCs embryonic stem cells) untersucht. Unsere Ergebnisse haben gezeigt, dass die Mitglieder der miRNA-290 Familie alleine nicht in der Lage sind, den Verlust der Pluripotenz während der Differenzierung von ESCs zu verhindern. Die Inhibition dieser miRNAs hingegen unterstützt den Differenzierungsprozess. Zusätzlich resultiert in ESCs die Überexpression der miR-290Gruppe in der Unterdrückung der Differenzierung in Richtung Mesoderm und Keimzellen möglicherweise über die Regulierung des Wnt-Signalweges. Zusammenfassend weisen diese Ergebnisse auf eine wichtige Funktion von miRNAs bei der Regulation der Differenzierung von ESCs hin.

Im zweiten Teil der vorliegenden Arbeit konnten wir zeigen, dass die ebenfalls Pluripotenz-assoziierte miRNA-302-Gruppe - im Gegensatz zu pluripotenten Zellen mit Keimbahn-Ursprung - in ESCs hoch exprimiert wird. Weiterhin identifizierten wir feine Unterschiede in den Expressionslevel von Keimzellmarker-Genen zwischen ESCs und den Keimbahn-entstammenden pluripotenten Zelltypen maGSCs (multipotent adult germline stem cells) und EGCs (embryonic germ cells). Interessanterweise war die Expression der Keimzellmarker-Gene negativ korreliert mit der Expression der miRNA-302 Familienmitglieder. Dementsprechend habe wir gefunden, dass die Überexpression der miRNA-302-Gruppe in maGSCs in der Herunterregulation der Keimzellmarker-Gene 
resultiert. Zusammenfassend lässt sich sagen, dass unsere Ergebnisse zeigen, dass die miRNA302-Gruppe die Differenzierung von ESCs in Richtung Keimbahn reguliert.

Im dritten Teil der vorliegenden Arbeit war es unser Anliegen, die miRNA-Signatur verschiedener Keimzellstadien zu etablieren. Um dieses zu erreichen, haben wir eine doppelttransgene Maus (Stra8/EGFP und Sycp3/DsRed) generiert, mit deren Hilfe wir reine Keimzellpopulationen aus dem Hoden der Maus isolieren konnten. Wir haben die miRNAExpressionsprofile von spermatogonialen Stammzellen (SSCs - spermatogonial stem cells), premeiotischen (grünen) und meiotischen (roten) Keimzellen miteinander verglichen. Mit Hilfe dieses Ansatzes war es uns möglich, Stadien-spezifische miRNAs zu identifizieren, und wir konnten zeigen, dass z.B. miRNA-221, -203 und -34b-5q ihre Zielgene c-Kit, Rbm44 und Cdk66 regulieren und so die Spermatogenese beeinflussen. Zusammenfassend haben wir in dieser Studie das räumliche und zeitliche Expressionsprofil von miRNAs sowie deren möglichen Funktionen in der Spermatogenese beschrieben.

Zusätzlich konnten wir zwei neue Pluripotenz-spezifische miRNAs identifizieren: miRNA-135b und miRNA-363. Die Funktion dieser neuen Pluripotenz-spezifischen miRNAs wird zurzeit untersucht. Desweiteren haben wir über die Verwendung unserer doppelttransgenen Maus eine Reihe bisher nicht charakterisierter Meiose-spezifischer Gene identifiziert. Im Moment werden diese Meiose-spezifischen Gene auf molekularer und biochemischer Ebene charakterisiert und bezüglich ihrer Funktionen während der Meiose untersucht. 


\section{Summary}

For quite a long time, non-coding RNAs (ncRNAs) were discriminated and considered as an evolutionary error. In light of this opinion, discovery of small ncRNAs, in particular microRNA (miRNA), which can regulate the gene expression post-transcriptionally, was a surprise. Computational and experimental approaches revealed the presence of miRNA in almost all living organisms, including plants and Homo sapiens. Growing body of evidence suggests that miRNAs play a crucial role in different aspects of life, ranging from regulation of single cell metabolism through controlling of cell fate and development of multicellular organisms. The present thesis is aimed at understanding the function of miRNAs in pluripotent stem cells and in spermatogenesis.

In the first part of this thesis, we studied the role of miRNA-290 cluster, a pluripotencyrelated miRNA cluster, during differentiation of embryonic stem cells (ESCs). Our results show that miRNA-290 family members are not sufficient to prevent the loss-of-pluripotency during induced differentiation of ESCs. However, inhibition of these miRNAs was found to facilitate the differentiation process. In addition, overexpression of miR-290 cluster in ESCs resulted in prevention of differentiation towards mesoderm and germ cells, possibly through modulation of Wnt-signaling pathway. Collectively, these results support the assumption that miRNA-290 members are included in regulation of differentiation fate of ESCs.

In the second part of this thesis, we identified that ESCs but not germline derived pluripotent stem cells retain high expression levels of miRNA-302 cluster, another pluripotency-related miRNA clusters. Further, we found out subtle differences in expression levels of germ cell marker genes between ESCs and germline derived pluripotent cell types such as multipotent adult germline stem cells (maGSCs) and embryonic germ cells (EGCs). Interestingly expression of germ cell marker genes was negatively correlated with expression of miRNA-302 family members. In agreement with these observations overexpression of miRNA-302 cluster in maGSCs resulted in downregulation of germ cell marker genes. Taken together, our results highlight that miRNA-302 cluster regulates differentiation of ESCs to the germ cell lineage.

In the third part of this thesis, we made an attempt to establish the miRNA signature of various stage-specific germ cells. Towards this end, we generated a double transgenic mouse model (Stra8/EGFP and Sycp3/DsRed), which helped us to obtain pure germ cell populations from mouse testis. Next, we compared miRNA expression profiles between spermatogonial 
stem cells (SSCs), pre-meiotic (green) and meiotic (red) cells. Through this study, we identified that stage-specific miRNAs, i.e., miRNA-221, -203 and $-34 b-5 p$ regulate their corresponding targets such as $c$-Kit, Rbm44 and Cdk6 to orchestrate the spermatogenesis process. To sum up this study, we described spatiotemporal expression pattern of miRNAs and their possible functions during spermatogenesis.

In the present study, we also identified two novel pluripotent cell-specific miRNAs: miR-135b and miR-363. The function of these novel pluripotency-related miRNAs is under investigation. Furthermore, using our double transgenic mouse model, we identified several uncharacterized meiotic cell-specific genes. Currently, the molecular and biochemical characterization of these genes and their functions during meiosis is under the way. 


\section{Introduction}

Gene expression is a process by which the information encoded in gene sequences is transcribed and mostly translated into gene product and is common for all living organisms. The course of gene expression is regulated in a simple way in Prokaryotes and becomes more complicated in Eukaryotes. Several steps during this process can be regulated, including remodeling of chromatin structure, generation and transport of transcripts, posttranscriptional modification and finally protein translation and post-translational modifications. Regulation of gene expression gives the cells possibilities to control their behavior and function, and defines cells fate. This regulatory mechanism explains how cells sharing the same genome can be so different from each other. For quite a long time, only proteins were considered as regulatory tools of cellular identity. Due to this fact, screening for new regulatory molecules was focused on protein level. Although the function of some regulatory genes was well documented, the protein products of these genes have never been identified, but rather led to the discovery of non-coding RNAs (ncRNAs) (Eddy, 2001). Interaction of ncRNA with either DNA or mRNA results in regulation of gene expression (mostly repression). MicroRNA (miRNA or miR) is one of the most abundant ncRNA families regulating gene expression in a post-transcriptional manner (Bartel, 2004). The goal of this thesis is the identification and functional characterization of miRNAs which are specific for pluripotent stem cells and for various cell types of mouse spermatogenesis. Hence, the regulation and function of miRNAs, in general, as well as their crucial role in maintenance of pluripotency and regulation of spermatogenesis will be emphasized in the following sections.

\section{1. miRNA biogenesis}

The first miRNA was described independently by two groups in 1993 (Lee et al., 1993; Wightman et al., 1993). Both research groups have found that the product of the lin-4 gene, which negatively regulates the lin-14 gene expression in Caenorhabditis elegans $(C$. elegans), is not a protein but two small RNAs derived from it (Lee et al., 1993; Wightman et $a l .$, 1993). Forward genetic approach identified that lin-4 RNAs interact with 3' untranslated region (3' UTR) of lin-14 gene and led to propose a new mechanism for the regulation of gene expression (Wightman et al., 1991; Wightman et al., 1993). This innovative hypothesis was rather considered as an exception until the year 2000 when let-7, the second example of 
such transcription regulatory-RNA was discovered (Reinhart et al., 2000). Let-7 represses lin41 expression and, similar to previously described lin-4, regulates developmental timing in $C$. elegans (Reinhart et al., 2000). Due to their functions in temporal development in worms, these small RNAs were initially named as small temporal RNAs (stRNAs) (Pasquinelli et al., 2000). This name was later changed to microRNA when several research groups discovered that stRNA is not only limited to worm world, but is generally expressed in invertebrates as well as in mammals and plants (Lagos-Quintana et al., 2001; Lau et al., 2001; Lee and Ambros, 2001; Reinhart et al., 2002). Together with the large number of newly discovered miRNAs in almost all known organisms, it became evident that miRNAs represent a conserved pathway for the regulation of gene expression (Ambros, 2004; He and Hannon, 2004).

The mechanisms underlying miRNA biosynthesis are highly conserved and involve two sequential steps: (1) generation of $\sim 70$ nucleotides (nt) precursor miRNA (pre-miRNA) originating from a longer primary miRNA transcript (termed pri-miRNA), (2) processing of the pre-miRNA into mature $22 \mathrm{nt}$ miRNA. Figure 2.1. presents an overview of the canonical pathway of miRNA synthesis in animals. Typically, the pri-miRNA transcript is generated by a RNA polymerase II-mediated process and includes one or more internal stemloop hairpin structures containing the miRNA sequences (Cai et al., 2004; Lee et al., 2004). In the first step, the stem-loop structure is recognized and cleaved in the nucleus by microprocessor complex consisting of RNaseIII endonuclease Drosha and its cofactor DGCR8 (known as Pasha in Drosophila melanogaster (D. melanogaster) and C. elegans) which executes enzymatic function and the cleavage site identification, respectively (Lee $e t$ al., 2003; Denli et al., 2004; Han et al., 2004; Han et al., 2006). Drosha cleaves at the base of the stem and releases pre-miRNAs which are exported from the nucleus to the cytoplasm by Exportin-5 in the presence of Ran-GTP cofactor (Yi et al., 2003). In the cytoplasm, the hairpin structure of pre-miRNA is processed by another RNaseIII endonuclease Dicer (Hutvagner et al., 2001; Ketting et al., 2001). Dicer cooperates with double strand RNA (dsRNA) binding protein TRBP (RDE-4 in C. elegans and Loquacious in D. melanogaster) to cleave the loop and thereby generates miRNA duplex (Tabara et al., 2002; Haase et al., 2005). Generally, only one miRNA from the duplex, termed major or guide, is functional, another one (minor, miRNA* or passenger miRNA) has no known function and becomes degraded (Schwarz et al., 2003). The Dicer product (major miRNA) together with Argonaute proteins form miRNA-induced silencing complex (miRISC) which mediates posttranscriptional gene suppression (MacRae et al., 2008). In principle, miRNA recognizes 
complementary sequences in the 3' UTR of the targeted genes. Mechanisms by which major/mature miRNA executes its function depend on the degree of complementarity between miRNA and its target mRNA. Full complementarity causes mRNA degradation while partial complementarity results in translation inhibition. Degradation of mRNA targets in context of full complementarity is mostly restricted to plants (Bartel, 2004). In animals, miRNAs bind to their target mRNAs through imperfect complementarity at multiple sites leading to translational repression rather than target degradation. Therefore one miRNA can regulate the expression of more than one target gene, and individual target genes can be simultaneously targeted by several miRNAs (Doench and Sharp, 2004; Lim et al., 2005). Through the repression of target genes expression, miRNAs are involved in a wide variety of biological processes including developmental timing, cell proliferation and differentiation, cell cycle regulation, cell death and metabolism. Aberrant expression of many miRNAs has already been linked with developmental abnormalities and human diseases (Osman, 2012).

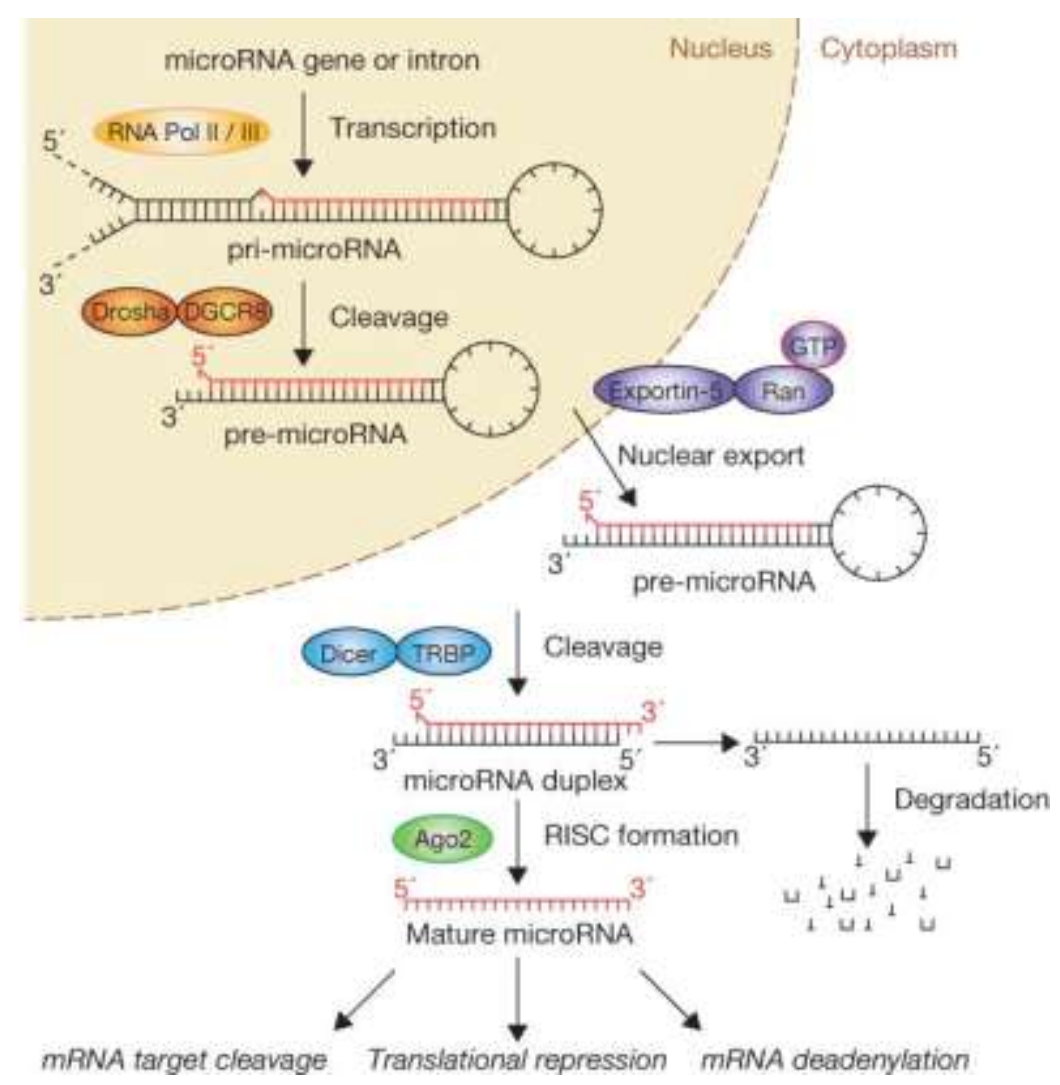

Figure 2.1. Schematic representation of canonical miRNA biosynthesis pathway. Canonical pathway of miRNA processing includes production of primary transcript (pri-miRNA) either by RNA polymerase II or occasionally by RNA polymerase III. Nascent pri-miRNA transcript is further processed by microprocessor complex (Drosha-DGCR8) in the nucleus. The resulting precursor (pre-miRNA) is exported from the nucleus to the cytoplasm by Exportin-5-RanGTP complex. Dicer together with TRBP cleaves pre-miRNA to give rise to miRNA duplex. Finally only one strand from the duplex (termed mature or major) is loaded onto miRISC and 
regulates the gene expression either by mRNA cleavage or translation repression. The other strand has no known function and is mostly degraded (figure adopted fromWinter et al., 2009).

\subsection{Regulation of miRNA expression}

Although the mechanism of miRNA biogenesis is well described, only a few studies illustrate the regulation of this process. Till now, no universal mechanism for miRNA maturation is proposed and most of our knowledge comes from examples of biosynthesis regulation of single miRNAs, miRNA clusters or only a subset of miRNAs (Krol et al., 2010). Regulation of miRNA genesis can occur throughout each step of miRNA expression and maturation including pri-miRNA transcription, processing of pri-miRNA to pre-miRNA, export of pre-miRNA from nucleus to the cytoplasm, miRNA duplex formation, assembling of miRISC and finally modulation of mature miRNA.

Mechanisms controlling the gene expression at the transcriptional level are common for protein-coding genes as well as for miRNAs. During transcription many DNA-binding proteins like c-Myc, p53 or cell-specific transcription factors can bind to miRNA promoter region and regulate its expression in a tissues-specific or developmental-specific manner (O'Donnell et al., 2005; Lin et al., 2009; Boominathan, 2010). Moreover, miRNA genes can be regulated by epigenetic modifications (DNA methylation and histone modifications) occurring at their promoter region or at neighbouring locus (Saito et al., 2006; Lujambio et al., 2008; Lujambio and Esteller, 2009).

Once the transcriptional process is finished, different mechanisms regulate the maturation of mRNAs and miRNAs. The pri-miRNA transcript processing into mature miRNA involves two-step digestion mediated by Drosha and Dicer. Regulation of this stage entails post-transcriptional modification of enzymes or RNA template structure and control of interaction between both RNA and protein molecules. Interaction of Drosha with DEAD box RNA helicases p68 and p72 enables recruitment of other proteins (i.e. R-Smad, p53 or estrogen receptor- $\alpha$ ) and regulates miRNA maturation (Davis et al., 2008; Suzuki et al., 2009; Yamagata et al., 2009). The well-known example of RNA structure modification includes interaction between Lin28 or complex of nuclear factor 90 and nuclear factor 45 (NF90/NF45) with members of the let-7 family (Newman et al., 2008; Rybak et al., 2008; Sakamoto et al., 2009). Lin28 binds to a specific sequence in the let-7 stem-loop structure and inhibits its maturation by changing the pri-miRNA conformation (Nam et al., 2011). Unlike Lin28, interaction of heterogeneous nuclear ribonucleoprotein A1 (hnRNP A1) and KH-type splicing regulatory protein (KSRP) with the loop of pri-miR-18a and pri-miR-206, 
respectively, promote pri-miRNA processing (Michlewski et al., 2008; Trabucchi et al., 2009). In addition, the maturation process can be regulated during export of pre-miRNA from the nucleus as well as during the incorporation of mature miRNA into the RISC complex. However, both mechanisms are poorly understood. A recent study has identified $\sim 12$ nt semimicroRNAs (smiRNA) which are generated along the miRNA pathway and are capable of regulating the activity of corresponding mature miRNAs (Plante et al., 2012).

\section{3. miRNA annotation and registry}

Together with the increasing number of newly discovered microRNAs it was necessary to develop a uniform system for miRNA annotation. In the year 2003, Victor Ambros and colleagues described a set of rules for the experimental verification of newly discovered miRNAs based on the expression and biogenesis criteria (Ambros et al., 2003). Moreover, they proposed also a convention for nomenclature of miRNAs. To improve the communication between miRNA research groups, Sanger Institute created a miRNA registry (miRBase) (Griffiths-Jones, 2004). This registry serves as a platform to submit new miRNAs on one hand and provides detailed information about each published miRNA, on the other hand. The $19^{\text {th }}$ release of miRBase is available since August 2012 and contains information about 25141 mature miRNAs in 193 species.

\section{4. miRNA functions in animal development}

Together with the discovery of lin-4 and let-7 functions, miRNAs have been classified as regulators of developmental processes (Lee et al., 1993; Wightman et al., 1993). The miRNA loss-of-function models displayed abnormalities during C. elegans larval maturation due to precocious or retarded development (Chalfie et al., 1981; Ambros and Horvitz, 1984). Due to their high evolutionary conservation, lin-4 and let-7 miRNAs are suggested to perform the same function in other species (Pasquinelli et al., 2000; Lagos-Quintana et al., 2002). This hypothesis was further supported by the results of knock out (KO) experiments, where organisms with defective miRNA biogenesis were used as a tool for characterization of miRNA function. Depletion of Dicer, Drosha or Argonaute proteins was found to result in embryonic lethality in all tested animal models (Grishok et al., 2001; Bernstein et al., 2003; Wienholds et al., 2003; Alisch et al., 2007; Park et al., 2010). Classical Dicer-KO mouse models displayed embryonic lethality at 7.5 day post coitum ( $\mathrm{dpc}$ ) due to the lack of stem cells, whereas conditional-KO resulted in defective proliferation and differentiation of 
embryonic stem cells (ESCs) (Bernstein et al., 2003; Kanellopoulou et al., 2005). These results suggest that miRNAs are necessary for maintenance of stemness as well as for differentiation of pluripotent stem cells, where stage-specific miRNA might regulate the expression of target genes important for tissues development and/or their proper function. Following this observation, many research groups have started to analyze miRNA profiles of specific cell-types, tissues and organs in an attempt to elucidate their biological functions (Stefani and Slack, 2008). Upon the identification of a specific miRNA, its target mRNAs can be predicted using several web-based tools (Xia et al., 2009). To verify the interaction between a miRNA of interest and its corresponding target, a simple assay was established (Nicolas, 2011). This assay is based on the expression of chimeric gene (e.g. luciferase ORF fused with 3'UTR of target of interest) upon miRNA overexpression. Finally, the interaction and regulation of target gene expression at protein level must be confirmed in vivo in a physiological condition. Development of miRNA microarray and deep sequencing technologies paved the way for the current golden age of miRNA research by replacing complicated and time consuming approaches for miRNA identification (Barad et al., 2004; Liu et al., 2004; Creighton et al., 2009). Data obtained from the comparison of miRNA profiles of normal or defective tissues thus illustrate the importance of a specific miRNAs. The well-known example includes miRNA miss-expression in many types of human cancer (Kong et al., 2012).

\subsection{Role of miRNAs in pluripotent stem cells}

Pluripotent stem cells are defined by two main characteristics: they are able to selfrenew and can differentiate towards derivatives of all three germ layers and to germ cells (Bradley et al., 1984). Since 1981, when Evans and Kaufman first established a protocol for the isolation and culture of mouse ESCs, these ESCs became the gold standard of pluripotency and model for further characterization (Evans and Kaufman, 1981). Understanding the molecular basis of ESCs self-renewal and differentiation properties would facilitate their use in future regenerative medicine applications. Among many identified factors, Oct4, Sox2, Klf4, c-Myc and Nanog compose a core transcription factor network regulating the stemness of pluripotent stem cells (Niwa, 2007). Interestingly, forced expression of these transcription factors allows the reprogramming of somatic cells into pluripotent cells, widely known as induced pluripotent stem cells (iPSCs) (Takahashi and Yamanaka, 2006; Takahashi et al., 2007; Yu et al., 2007). 
Since Dicer and Dgcr8-knockouts resulted in embryonic lethality due to depletion of stem cells, it signified a need for identification of individual pluripotency-specific miRNAs and to elucidate their role in pluripotency. Till now, members of miR-290 family (miR-371 family is human homolog) and miR-302 family were identified and characterized as specific for both mouse and human ESCs (Houbaviy et al., 2003; Suh et al., 2004). Moreover, miR290 family is expressed highly in the other pluripotent cell lines including embryonic germ cells (EGCs), multipotent adult stem cell (maGSCs) and embryonic carcinoma cells (ECCs) (Zovoilis et al., 2008; Zovoilis et al., 2010). Interestingly, the expression of these pluripotency-specific miRNAs is regulated by the core pluripotency transcription factor network, suggesting their involvement in a common molecular pathway of pluripotency maintenance (Marson et al., 2008). Although, ESC-specific miRNAs have a crucial role in maintenance of stemness, only a few studies enlightened their precise function. In general, members of ESC-expressed miRNAs promote pluripotency by regulating the cell cycle (Card et al., 2008; Wang et al., 2008; Lichner et al., 2011). In addition, the NFKB signalling pathway was reported as a target of miR-290 family to promote the pluripotency by suppressing differentiation and epithelial-to-mesenchymal transition (Luningschror et al., 2012). Recent studies have shown that ESC-specific miRNAs not only regulate the stemness but also facilitate somatic cells reprogramming towards iPSCs (Judson et al., 2009; Lin et al., 2011). Besides ESC-specific and cell cycle-regulating miRNAs, several miRNAs including miR-200 family, miR-205 and three miRNA clusters, miR-17 92, miR-106b 25 and miR106a 363 have been shown to regulate the reprogramming process by facilitating mesenchymal-to-epithelial transition (Gregory et al., 2008; Gregory et al., 2011; Li et al., 2011). Despite the well-known influence of miRNAs in pluripotency regulation, many challenges remain to elucidate the underlying mechanisms.

\section{6. miRNA functions during male germ cells specification}

Germ cells are the only cells in the body capable of transmitting genetic information through the generations by either oogenesis or spermatogenesis. Spermatogenesis is the process which gives rise to haploid male gametes and is common for all sexually reproducing animals. In mice, the process of spermatogenesis consists of three major phases: a) selfrenewal and proliferation, b) meiotic division, and c) spermiogenesis. Spermatogenesis is strictly regulated by transcriptional as well as post-transcriptional mechanisms (Cooke and Saunders, 2002; Bettegowda and Wilkinson, 2010). The transcriptional mechanisms are well 
described, however, the post-transcriptional regulation is still largely unknown (Pang et al., 2003; Wu et al., 2004). The support for the role of post-transcriptional mechanisms came from conditional knock out mouse models in which Dicer or Drosha were specifically depleted in primordial germ cells (PGCs) or spermatogonia (Hayashi et al., 2008; Maatouk et al., 2008; Korhonen et al., 2011). In all cases, the lack of miRNAs resulted in infertility due to disruption of spermatogenesis. To unravel the role of miRNAs in spermatogenesis, several research groups have performed expression analysis using purified germ cells or cells from the whole testis (Yu et al., 2005; Ro et al., 2007; Yan et al., 2007; Song et al., 2009). Although they were able to identify many miRNAs that are specific for certain germ cell populations, no functional studies were performed to explain the molecular function of these miRNAs. Till now there are only few examples of miRNAs with well documented function in spermatogenesis: a) miRNA-122a is expressed in late germ cells and targets Transition protein 2 gene (Tnp2) thus allowing the loading of protamines and subsequent chromatin compaction ( $\mathrm{Yu}$ et al., 2005), b) miRNA-21 which is highly expressed in spermatogonial stem cells (SSCs) and c) spermatocyte and spermatid-specific miRNA-34c are crucial for regulating apoptosis during spermatogenesis (Niu et al., 2011; Liang et al., 2012). In order to establish a comprehensive list of miRNAs and their functions during spermatogenesis, it is necessary to develop efficient strategies to enrich pure populations of various spermatogenic cell types. miRNA expression data obtained from such pure germ cell populations might help us to establish a spatiotemporal expression profile of miRNAs and to elucidate their function.

\subsection{Objectives}

To further expand our knowledge on the expression and function of miRNAs in pluripotent cells as well as in germ cells, the current study was undertaken with the following objectives:

1. Comparative expression and functional analysis of pluripotency-related miRNAs in various pluripotent cell types.

2. Identification of cell type-specific miRNAs and elucidation of their function during the process of spermatogenesis. 


\section{Results}

microRNAs (miRNAs) are a class of small non-coding RNAs known to function in post-transcriptional regulation of gene expression. The goal of this thesis was to characterize the function of known pluripotency-specific miRNAs. Moreover, we extended this study to germ cells and established the miRNA signature of various cell types of mouse spermatogenesis and showed functional relevance for some of the stage-specific miRNAs. Collectively, we revealed the miRNA profiles of pluripotent cells as well as germ cells and uncovered their function in regulation of pluripotency and spermatogenesis, respectively. The results of this thesis are summarized in the following manuscripts:

3.1. Members of the miR-290 cluster modulate in vitro differentiation of mouse embryonic stem cells.

3.2. Embryonic stem cell-related miRNAs are involved in differentiation of pluripotent cells originating from the germ line.

3.3. MicroRNA signature in various cell types of mouse spermatogenesis: Evidence for stage-specifically expressed miRNA-221, -203, and -34b-5p mediated spermatogenesis regulation.

Each paragraph within the following results section contains a brief description of the aim of the study in context of the complete thesis, the status of each manuscript as well as the author contributions. 


\subsection{Members of the miR-290 cluster modulate in vitro differentiation of mouse embryonic stem cells}

Recent studies have highlighted the importance of miRNAs, especially miR-290 family members, in maintenance of self-renewal and proliferation properties of pluripotent stem cells. In the first part of this thesis, we tested the possible function of miRNA-290 members during embryonic stem cell (ESC) differentiation. Towards this end, we performed miRNA gain-of-function and loss-of-function experiments in ESCs. The overexpression of miR-290 cluster in ESCs could not prevent the downregulation of Oct4, a pluripotency marker gene, and also failed to sustain the stemness during induced differentiation. However, the suppression of miRNA-290 members expression resulted in an immediate downregulation of Oct4 and cells showed precocious differentiation. Additionally, differentiation towards mesoderm and germ cell lineage was found to be significantly affected in miR-290 cluster overexpressing cells. Reciprocally, the miR-290 cluster suppression resulted in preferential derivation of mesoderm and germ cell lineage cell types. Further studies revealed that miRNA-290 members target Dkk1, a Wnt-signaling inhibitor, to modulate the mesoderm and germ cells differentiation of ESCs. Collectively, our results demonstrate for the first time that pluripotent-specific miRNAs regulate the differentiation of ESCs.

Authors: Athanasios Zovoilis*, Lukasz Smorag*, Angeliki Pantazi, Wolfgang Engel. * equal contribution to the work

Published in Differentiation. 2009 Sep-Oct;78(2-3):69-78. doi: 10.1016/j.diff.2009.06.003. Epub 2009 Jul 22. 


\subsection{Embryonic stem cell-related miRNAs are involved in differentiation of pluripotent cells originating from the germ line.}

We have identified that the expression of miR-290 as well as miR-302 clusters is identical between undifferentiated pluripotent cells originating either from inner cell mass of the blastocyst (ESCs) or from germ cells (multipotent adult germline stem cells (maGSCs)). However, we noted that maGSCs retain high expression levels of miR-290 cluster, which is associated with high Oct4 expression, during induced differentiation. In the second part of this thesis, we investigated the potential differences between ESCs and maGSCs as well as embryonic germ cells (EGCs) during differentiation and the relevance of miRNAs in this process. We found that undifferentiated maGSCs and EGCs express high levels of germ cell specific marker genes such as Dppa3 and Stra8 compared to ESCs. These expression levels were highly persistent even during the differentiation of maGSCs and EGCs. In light of these findings, we identified that ESCs but not maGSCs retains high expression levels of miRNA302 cluster during differentiation and inversely correlates with the levels of early-germ cell marker genes. Finally as a proof of concept, we show that overexpression of miR-302 in maGSCs can suppress the preferential differentiation into germ cell lineage during differentiation.

Authors: Athanasios Zovoilis*, Angeliki Pantazi*, Lukasz Smorag*, Lennart Opitz, Gabriela Salinas Riester, Marieke Wolf, Anna Holubowska, Ulrich Zechner, Stewart Colin, Wolfgang Engel

\section{* equal contribution to the work}

Published in Mol Hum Reprod. 2010 Nov;16(11):793-803. doi: 10.1093/molehr/gaq053. Epub 2010 Jun 21. 
3.3. MicroRNA signature in various cell types of mouse spermatogenesis: Evidence for stage-specifically expressed miRNA-221, -203, and -34b-5p mediated spermatogenesis regulation.

Spermatogenesis, the process of haploid male gametes generation, is a complex process regulated by both transcriptional and post-transcriptional mechanisms. To better understand how post-transcriptional mechanisms mediated by miRNAs regulate the self-renewal as well as differentiation process of spermatogonial stem cells (SSCs), we analyzed the miRNA expression profile of various cell types of mouse spermatogenesis. To achieve this goal, we generated a transgenic mouse model (Stra8/EGFP and Sycp3/DsRed) in which pre-meiotic (PrM) and meiotic cells were marked by EGFP and DsRed, respectively. The isolation of pure germ cell populations, i.e., SSC, PrM and meiotic cells and the subsequent miRNA microarray expression analysis led us to establish the miRNA signature of individual cell type. Through functional studies, we show that miRNA-221 regulates the self-renewal of SSCs by targeting $c$-Kit, while miRNA-203 and -34b-5p function in preventing the precocious activation or repression of germ cell differentiation by targeting Rbm44 and Cdk6, respectively. Taken together, through our data we suggest a working model where spatiotemporal expression of miRNA functions in the regulation of spermatogenesis.

Authors: Lukasz Smorag, Ying Zheng, Jessica Nolte, Ulrich Zechner, Wolfgang Engel, D.V. Krishna Pantakani.

Published in Biol Cell. 2012 Nov;104(11):677-92. doi: 10.1111/boc.201200014. Epub 2012 Sep 24. 


\section{Discussion}

Since the first discovery of miRNAs in $C$. elegans about 20 years ago, now they are identified in almost all living organisms. As much as $60 \%$ of human protein-coding genes might be regulated by miRNAs (Lewis et al., 2005; Friedman et al., 2009). Deregulation in miRNAs expression has been already reported to be associated with many human diseases, in particular with cancer. Moreover, miRNAs were shown to be essential for maintenance of stem cells as well as for normal embryogenesis (Bernstein et al., 2003). In the present study, we investigated the expression and function of microRNAs in pluripotent stem cells as well as in germ cells. We have shown that miRNAs belonging to miR-290- and 302-clusters regulate the fate of pluripotent stem cells by suppression of differentiation pathways towards mesoderm and germ cell lineage. Moreover, we established miRNA expression profile of spermatogonial stem cells (SSCs), premeiotic and meiotic cells. Further, we have shown that germ cell specific miRNA-221, -203 and 34-5p regulate their corresponding target genes ( $c$ Kit, Rbm44 and Cdk6, respectively) to control the spermatogenesis. Taken together, our current studies revealed novel functions of pluripotent stem cells- and germ cell-specific miRNAs in the context of pluripotency and spermatogenesis.

\subsection{Pluripotent stem cell-specific miRNAs and their functions}

ESC specific miRNAs, the members of miR-290 and miR-302 clusters, have been shown to regulate pluripotency (Houbaviy et al., 2003; Suh et al., 2004; Lakshmipathy et al., 2007; Morin et al., 2008). Moreover, these ESC-specific miRNAs are highly expressed in other pluripotent cell lines such as multipotent adult germline stem cells (maGSCs), embryonic carcinoma cells (ECCs), embryonic germ cells (EGCs) and induced pluripotent stem cells (iPSCs) (Zovoilis et al., 2008; Chin et al., 2009; Zovoilis et al., 2010). Similarly, members of miR-371 cluster (homolog of murine miRNA-290 family) and miRNA-302 cluster represent the majority of human ESC-specific miRNAs (Suh et al., 2004). Our current knowledge concerning the function of ESC-specific miRNAs comes from analysis of phenotypes caused by genetic ablation of components of miRNA biosynthesis pathway. Dicer knockout embryos dye during embryonic development and Dicer-deficient (Dicer ${ }^{-{ }^{-}}$) ESCs are viable but manifest proliferation and differentiation defects (Bernstein et al., 2003; Kanellopoulou et al., 2005; Murchison et al., 2005). Moreover, the Dicer-/- ESCs failed to form teratoma after injection into immunodeficient mice and showed incompetence to 
contribute to chimera formation after injection into the blastocyst (Kanellopoulou et al., 2005). Interestingly, Dgcr8, a co-factor of Drosha, deficient ESCs displayed a similar phenotype (Wang et al., 2007).

Under physiological conditions, ESCs display a unique cell cycle pattern. As compared to somatic cells, ESCs have extremely short G1 phase and a high proportion of the cells in Sphase (White and Dalton, 2005). Analysis of cell cycle in $\operatorname{Dicer}^{-/-}$or $\mathrm{Dgcr}^{\mathrm{O}^{-/}}$revealed that many cells accumulate in G1 cell cycle phase and show cell proliferation and growth defects (Murchison et al., 2005; Wang et al., 2008). Transfection of single miRNAs into Dgcr $8^{-/-}$ ESCs has shown that members of miR-290 cluster are sufficient to rescue the proliferation defect (Wang et al., 2008). The Cyclin E-Cdk2 complex has been reported to positively regulate G1/S transition in ESCs (Kato, 1999; Burdon et al., 2002). p21CIP, the protein product of Cdknla gene, is a well-known inhibitor of cyclin E-Cdk2 complex (Harper et al., 1993). Simultaneously, Cdknla is post-transcriptionally regulated by miRNA-290 cluster and in the absence of miRNA-290 it can efficiently inhibit cyclin E-Cdk2 function resulting in G1 arrest (Wang et al., 2008). Additionally, two members of cyclin E-Cdk2 pathway, Rbl2 (p107) and Lats2 were identified as direct targets of miRNA-290 cluster (Wang et al., 2008). In consistence with these results, Lichner and colleagues have shown that miR-290 cluster regulate not only G1/S but also G2/M transition (Lichner et al., 2011). Further, this study has identified Fbx15 and Wee1 as targets of miR-290 cluster. Fbx15 interacts with dynactin-1 and regulates the cell entry into $\mathrm{S}$ phase, while Wee1 inactivates Cdk1 protein and regulate G2/M transition (Tominaga et al., 2006; Zhang et al., 2007). The function of miRNA-290 cluster in cell cycle regulation is depicted in Figure. 4.1. 

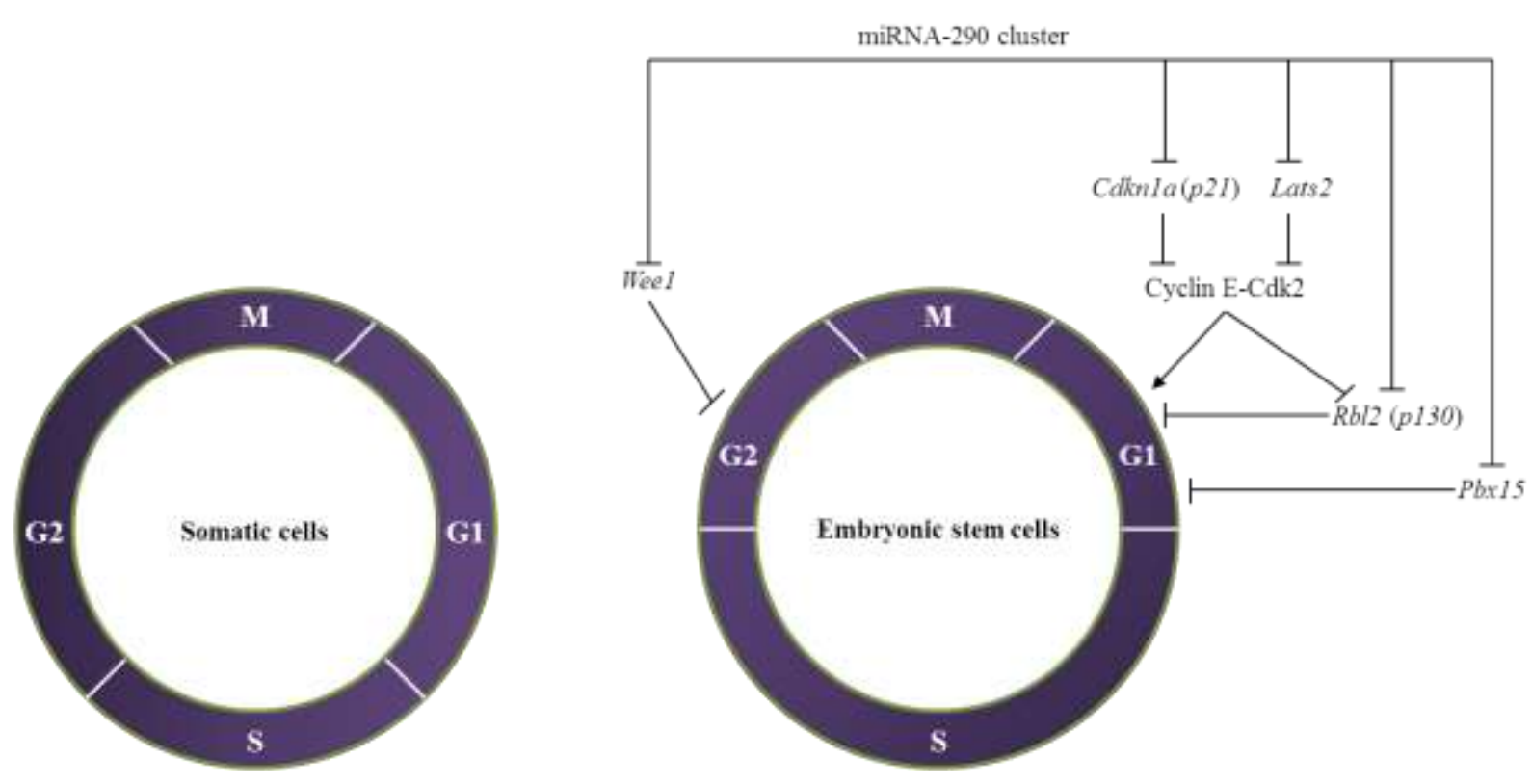

Figure 4.1. Cell cycle of somatic cells and ESCs. ESCs display unique cell cycle lacking fully formed gap phases G1 and G2. Moreover, most of the time (50-60\%) is dedicated for S phase in ESCs. Members of miRNA-290 cluster repress the expression of Cdkn1a and Lats2 to allow Cyclin E-Cdk2 mediated G1-S transition. Similarly, Rbl2, Pbx15 and Weel are inhibited by miR-290 members for G1-S and G2-M progression.

Although proliferation defects seen in Dicer $^{-/}$ESCs could be partially rescued by miR290 cluster, it was not sufficient to overcome differentiation defects (Sinkkonen et al., 2008; Wang et al., 2008). In line with these results, two research groups have shown that miRNA depletion results in inactivation of de novo methyltransferases (Dnmts) (Benetti et al., 2008; Sinkkonen et al., 2008). Due to the inactivation of DNA methylation machinery, core pluripotent transcription factors such as Oct4, Sox 2 and Nanog showed persistent expression during differentiation and cells retained the pluripotent state (Benetti et al., 2008; Sinkkonen et al., 2008). However, these results cannot rule out that other miRNAs depleted in Dicer ${ }^{-/}$ and $\mathrm{Dgrr}^{-/-}$cells are necessary for differentiation. This hypothesis is strengthened by the observation that the let-7 family members are highly expressed in ESCs during differentiation (Viswanathan et al., 2008).

In the present study (Zovoilis et al., 2009), we showed that ESC-specific miRNAs regulate stemness by suppression of genes involved in differentiation pathway. By employing gain-of-function and loss-of-function experiments in ESCs, for the first time we have shown that members of miRNA-290 family are sufficient to inhibit differentiation towards mesoderm and germ cells. We identified $D k k 1$, a well-known antagonist of Wnt signaling 
pathway as a direct downstream target of miRNAs of 290 cluster. In contrast to these observations, activation of Wnt signaling pathway was mostly correlated with activation of mesoderm formation (ten Berge et al., 2008). Since our knowledge about Wnt action in ESCs remains incomplete it is difficult to explain this discrepancy. In accordance to our study, Lichner et al.(2011) have shown that stable overexpression of miRNA-290 cluster in ESCs is sufficient to suppress expression of the early differentiation markers of all three germ layers. However, in our study we were not able to show any influence on differentiation towards endoderm and ectoderm lineage. This discrepancy most probably comes from technical limitation of transient transfections used in our study. In light of above findings, many research groups have tried to test the influence of miRNA-290 family on the reprogramming process. However, members of miRNA-290 cluster alone were not sufficient to reprogram somatic cells, but in combination with $O c t 4$, Sox 2 and Klf4, the efficiency of reprogramming was shown to be increased ten times (Judson et al., 2009). Since $c-M y c$ is one of the target genes of Wnt signaling, it is obvious that adding miRNA-290 cluster to the reprogramming cocktail can activate $c-M y c$ expression via Wnt pathway (Fig. 4.2). Indeed our results could show that overexpression of miR-290 cluster leads to the activation of $c$-Myc (Zovoilis et al., 2009). Collectively, these results strongly support the indispensable function of miRNAs in pluripotent stem cells as well as in normal animal development.

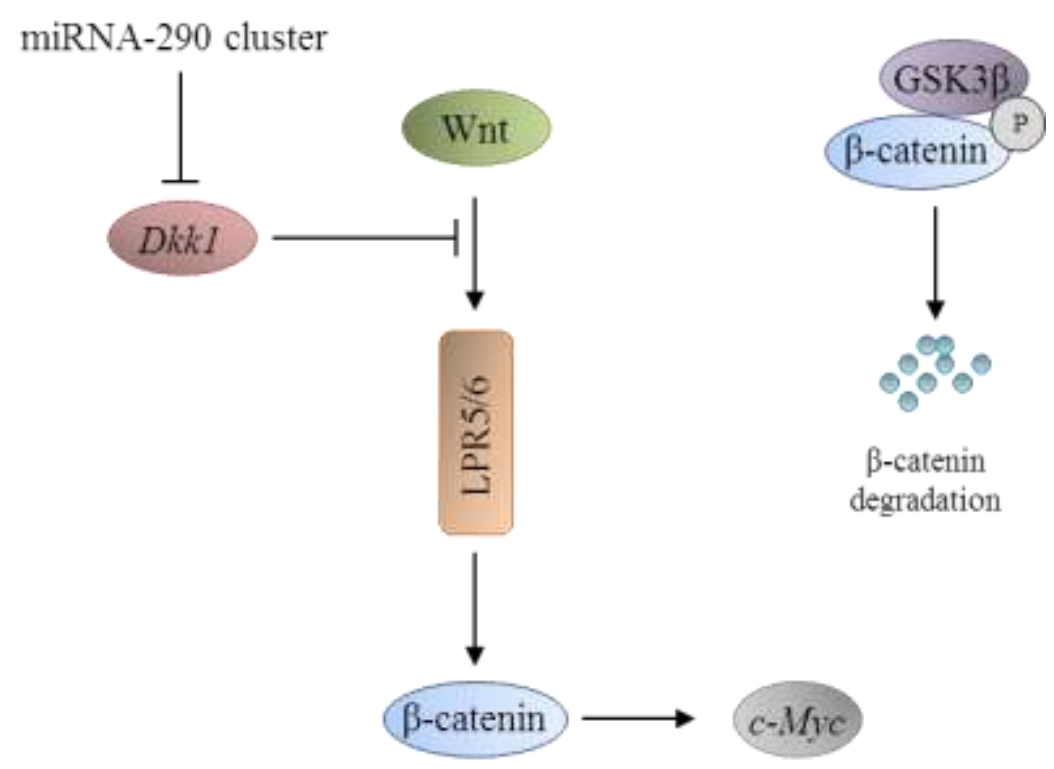

Figure 4.2. Schematic representation of the role of miRNA-290 cluster in Wnt signaling pathway. Suppression of Dkkl by miRNA-290 cluster enables binding of Wnts to the LPR5/6 receptor and prevents phosphorylation of $\beta$-catenin by GSK3 $\beta$. Next, the stabilized $\beta$-catenin translocates into the nucleus and activates the transcription of $c-M y c$. 


\subsection{Identification of novel pluripotency-related miRNAs}

In order to identify novel miRNAs which can play a crucial role in pluripotent stem cells, we compared miRNA expression profiles between pluripotent ESCs and embryonic fibroblasts (MEFs). This analysis led us to identify miR-130b, -124, -363-3p, and $-135 \mathrm{~b}$ as novel miRNAs expressed specifically in ESCs but not in MEFs (Fig. 4.3A). We observed a specific expression of miR-290 family members in ESCs (Fig. 4.3A), further validating our microarray analysis. We analyzed the expression of these novel miRNAs in several adult mouse tissues as well as in ESCs and found that miR-135b and -363 are preferentially expressed in ESCs (Fig. 4.3B), whereas miR-124 and -130b are found to be ubiquitously expressed (Fig. 4.3C), thus excluding them as pluripotent cell-specific miRNAs. To confirm the specific expression of miR-135b and -363 in pluripotent cells, we analyzed their expression in various pluripotent stem cell types and found them to be highly expressed in all analyzed cell types (Fig. 4.4A). Recently, several miRNAs were shown to play a major role during the reprogramming of somatic cell towards induced pluripotent stem cells (iPSCs) (Anokye-Danso et al., 2011; Kuo and Ying, 2012). To analyze the expression profile of novel miR-135b and -363 during reprogramming, we checked their expression during the time course of iPSCs generation. This analysis indicated that miR-135b and -363 start expressing at day7 of reprogramming along with the expression of pluripotency-related and mesenchymal-to-epithilial-transition inducing miRNAs, miR-294 and -200b, respectively (Fig. 4.4B). 
A.

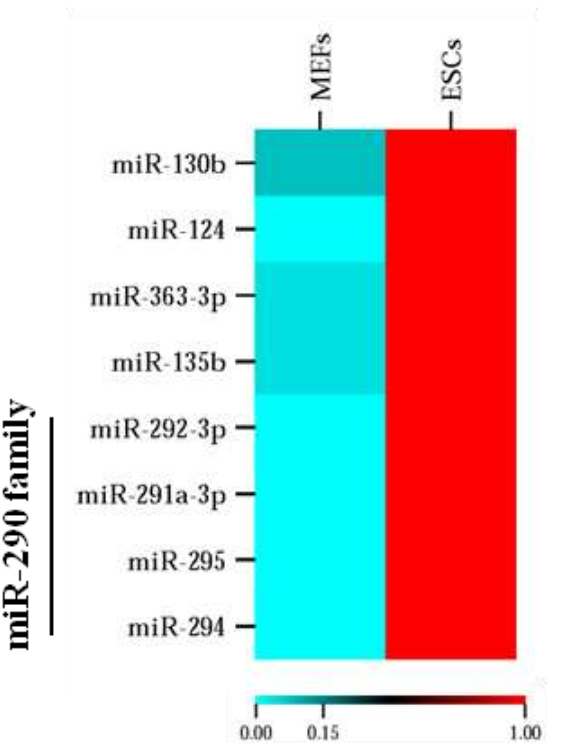

B.

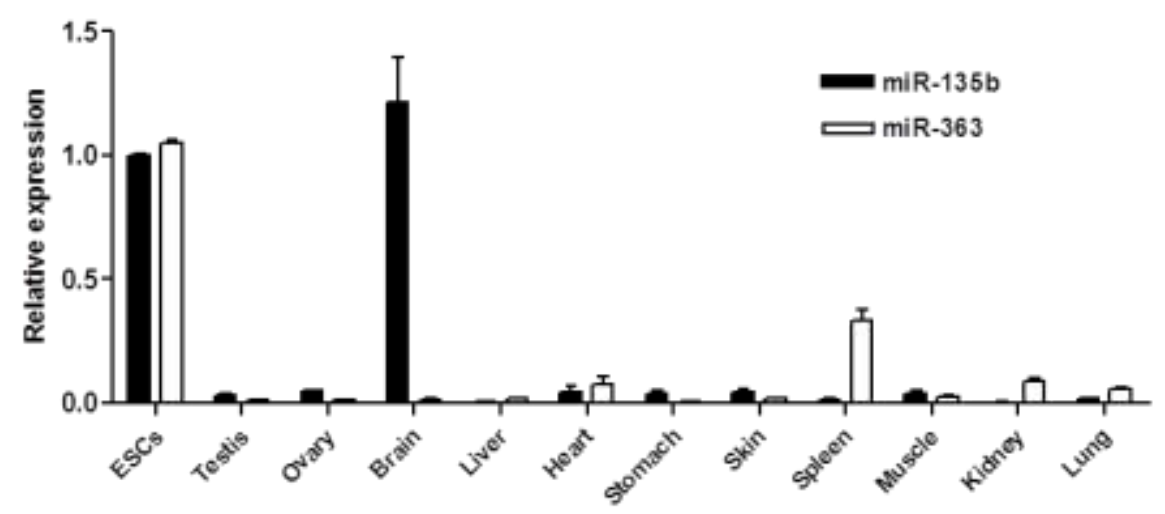

C.

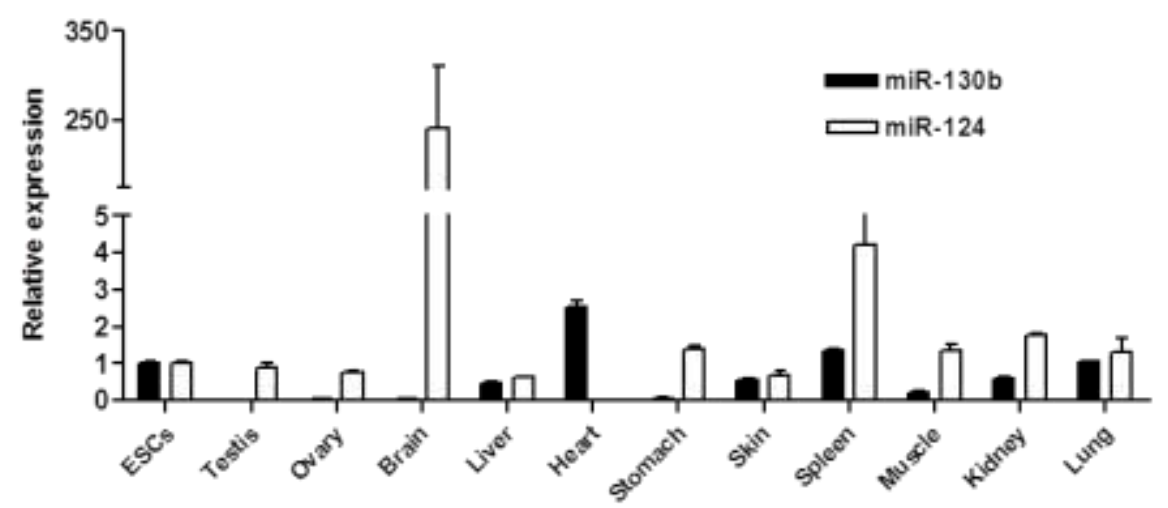

Figure 4.3. Identification and characterization of novel pluripotent cell-specific miRNAs. (A) Heat map representation of miRNA microarray data. The scale denotes an approximation of extent of miRNA relative upregulation in red and downregulation in cyan. Bar graph representation of qRT-PCR data showing the expression of miR-135b and miR-363 (B) as well as miRNA-130b and -124 (C) in various adult mouse tissues. 
A.

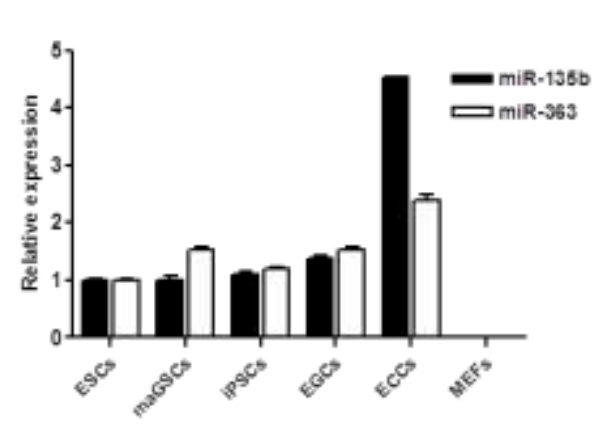

B.

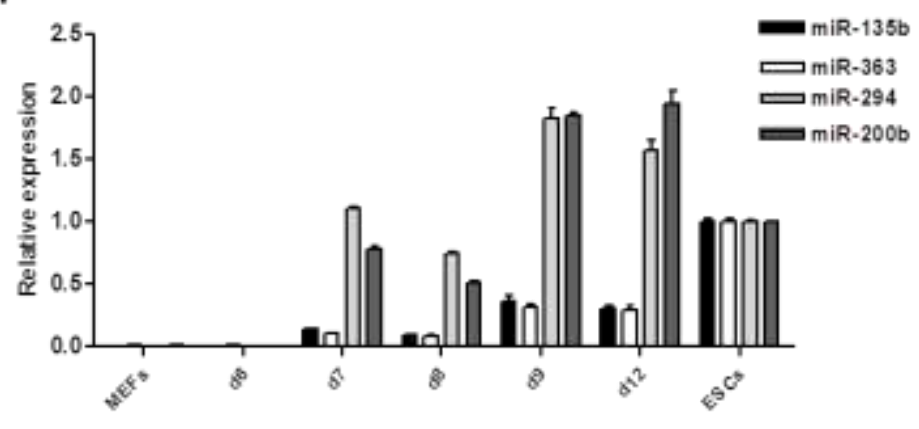

Figure 4.4 miR-135b and miR-363 are expressed in all pluripotent cell types. (A) Bar graph representation of qRT-PCR data of miR-135b and miR-363 in different pluripotent stem cell lines and in MEFs, a somatic cell type. (B) Bar graph showing the expression levels of miR-135b and miR-363 during somatic cell reprogramming time course.

\subsection{1. miRNA-135b and $\mathbf{- 3 6 3}$ are transcriptional targets of pluripotency-related factors}

The core pluripotency transcription factor network composed of Oct4 (O), Sox2 (S) and Nanog $(\mathrm{N})$ regulates the expression of several pluripotency-related genes to maintain the pluripotency (Loh et al., 2006; Chen et al., 2008; Marson et al., 2008). The transcriptional regulation by these core transcription factors thus indicates a gene as important for pluripotency maintenance. To identify whether miR-135b and -363 are transcriptionally regulated by the pluripotency network, we analyzed the publicly available chromatin immunoprecipitation-sequencing (ChIP-Seq) data of OSN binding sites across the mouse genome (Marson et al., 2008). This analysis indicated that OSN bind $\sim 4 \mathrm{~kb}$ proximal to miR$135 \mathrm{~b}$ and adjacent to -363 transcriptional start sites (Fig. 4.5A). To validate these observations, we performed ChIP using OSN antibodies on the chromatin prepared from ESCs and found a specific binding of OSN to the putative promoter regions of miR-135b and -363, albeit at various levels (Fig. 4.5B and 4.5C) 
A.

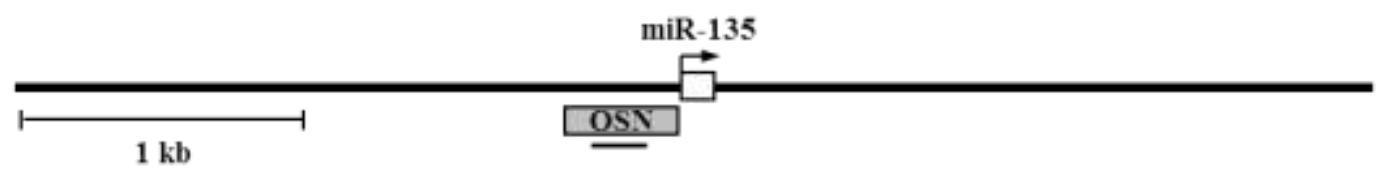

miR-106a-363 cluster

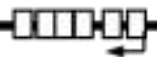

$1 \mathrm{~kb}$

B.

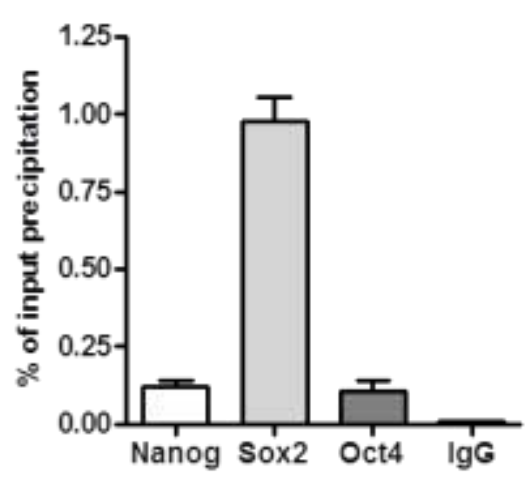

C.

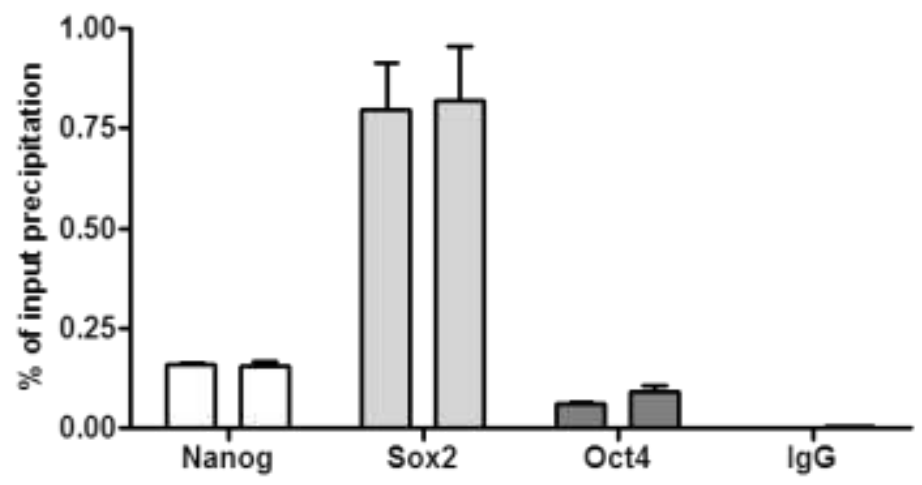

Figure 4.5. miR-135b and $\mathbf{- 3 6 3}$ are transcriptional targets of core pluripotency transcription factors. (A) The genomic architecture of miR-135b and miR-363 clusters along with the reported Oct4 (O), Sox2 (S) and Nanog (N) binding sites (Marson et al., 2008). The region analyzed for OSN binding using qRT-PCR is indicated as thick bar. Bar graph representation of OSN enrichment at the putative promoter regions of miR$135 \mathrm{~b}$ (B) and miR-363 (C). The ChIP with IgG served as a negative control.

\subsubsection{Identification of miR-135b and -363 target genes}

In order to identify mRNA targets of miR-135b and -363 , we used miRNA body map software to predict the targets of these two novel pluripotent cell-specific miRNAs. This analysis led us to identify cell cycle regulation and tumor suppressor genes as targets of miR135b (Fig. 4.6A). Similarly, miR-363 was predicted to target cell cycle regulators and differentiation-related genes (Fig. 4.6B). To experimentally validate these putative targets, we constructed luciferase reporters using the $3^{\prime}$-UTRs of two selected targets for each miRNA. ESCs transfected with cell cycle negative regulator (Ccng2), a miR-135b target, reporter construct and miR-135b-mimic showed $\sim 50 \%$ reduction in the luciferase reporter activity (Fig. 4.6C). However, tumor suppressor gene Rbll, another target of miR-135, showed no significant difference in luciferase reporter activity (Fig. 4.6C). Similarly, transfection of ESCs with cardiomyocyte differentiation factor (Nox4) reporter construct and 
miR-363-mimic showed $\sim 30 \%$ reduction in luciferase activity (Fig. 4.6D), whereas neurogenesis inducer (Myolb) showed no difference (Fig. 4.6D). Based on these results, we selected Ccng2 and Nox4 for further studies. Interestingly, we observed an inverse correlation in expression between miRNAs and their targets in undifferentiated ESCs as well as during induced differentiation (Fig. 4.6E, F). Further experiments aimed at understanding the function of these novel miRNAs and their targets during induced differentiation will uncover their role in pluripotency.

A.

\begin{tabular}{|l|l|l|}
\hline No. & Target Gene & Known/predicted Function \\
\hline 1 & Ceng2 (Cyclin G2) & Negative cell cycle regulation \\
\hline 2 & $\begin{array}{l}\text { Coce7/ (Cell division cycle associated 7- } \\
\text { like) }\end{array}$ & Roke in apoptosis \\
\hline 3 & Exo1 (Exonuclease 1) & DNA mismatch repair \\
\hline 4 & Hoxa10a (HomeoboxA 10) & Developmental processes \\
\hline 5 & Rad50 (Rad50 homolog) & Double strand breaks repair \\
\hline 6 & Rbif (Retinoblastoma like-1) & Tumor suppressor gene \\
\hline 7 & $\begin{array}{l}\text { Sash (Sem and Sh3 dom ain containing } \\
1)\end{array}$ & Tumor suppressor gene \\
\hline 8 & Zmar3 (Zinc finger, matrin-type 3) & Tumor suppressor gene \\
\hline
\end{tabular}

B.

B.
\begin{tabular}{|l|l|l|}
\hline No. & Target Gene & Known/predicted Function \\
\hline 1 & Nox4 (NADPH oxidase 4) & ESCs differentiation into smooth muscle cells \\
\hline 2 & Myotb (Myosin 1b) & Neuronal development \\
\hline 3 & Btg2 (Btg family, member 2) & $\begin{array}{l}\text { Antiproliferative, p53 dependent component of } \\
\text { ONAA dam age cellular response pattrway }\end{array}$ \\
\hline 4 & $\begin{array}{l}\text { Coknftc (Cyclin-dependent kinase } \\
\text { inhibitor 1C) }\end{array}$ & Inhibitor of several G1 cyclinvc dk complexes \\
\hline 5 & Hnffb (HNF1 homeobox B) & Differentiation towards visceral endoderm \\
\hline
\end{tabular}

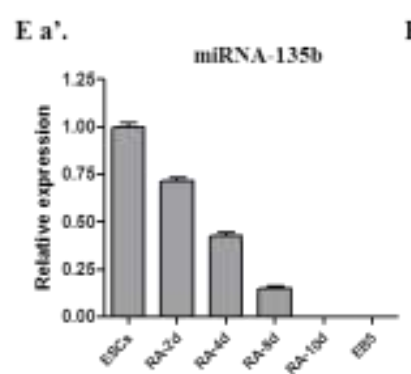

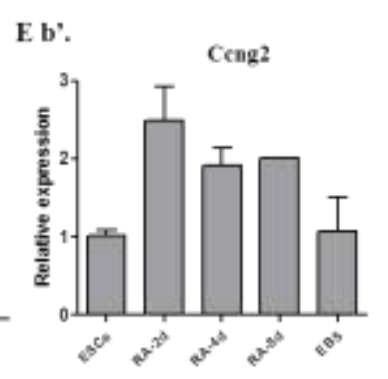

C.

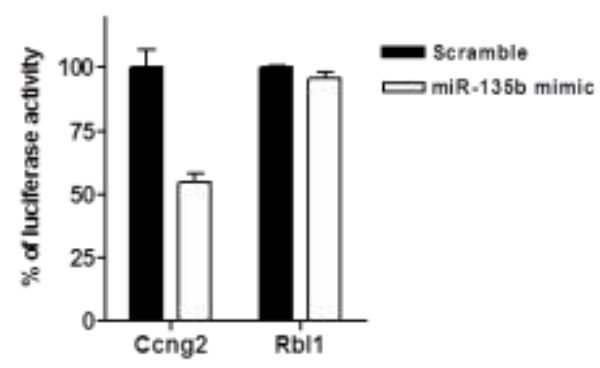

D.

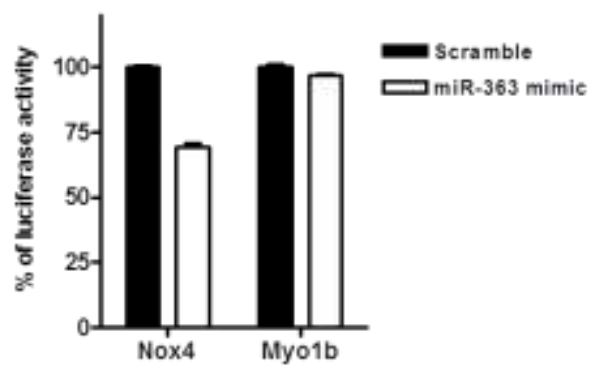

Figure 4.6. Identification and validation of putative target genes of miR-135b and -363. List of predicted target genes of miR-135b (A) and miR-363 (B). Bar graph showing the luciferase reporter activities of miR135b targets Ccng2 and Rbll (C), and miR-363 targets Nox4 and Myolb (D). (E) Bar graph representation of qRT-PCR data showing the expression of miR-135b (Ea') and its target Ccng2 (Eb') as well as miR-363 (Fc') and Nox4 (Fd') during the time course of retinoic acid (RA) induced differentiation of ESCs. 


\section{3. miRNAs in somatic cell reprogramming}

Generation of iPSCs by Takahashi and Yamanaka in 2006 opened up a new era in pluripotent stem cell research (Takahashi and Yamanaka, 2006). On the one hand iPSCs can overcome ethical issues associated with human ESCs and on the other hand they make it possible to generate patient specific stem cells and their use in cell replacement therapy by avoiding immune response. miRNAs are one of the factors which were shown to significantly enhance the efficiency of reprogramming process (Gregory et al., 2008; Li et al., 2011; Lin et al., 2011). The members of miR-290 cluster, miR-302, miR-17 92, miR-106b 25, miR106a 363 clusters as well as miR-200 cluster and miR-205 were reported to enhance the reprogramming process (Gregory et al., 2008; Li et al., 2011; Lin et al., 2011). Interestingly, majority of these miRNAs were proposed to regulate mesenchymal-to-epithelial transition (MET). Generation of iPSCs requires suppression of mesenchymal program and activation of epithelial program in somatic cells which is highly facilitated by miRNAs (Fig. 4.7) (Li et al., 2010).

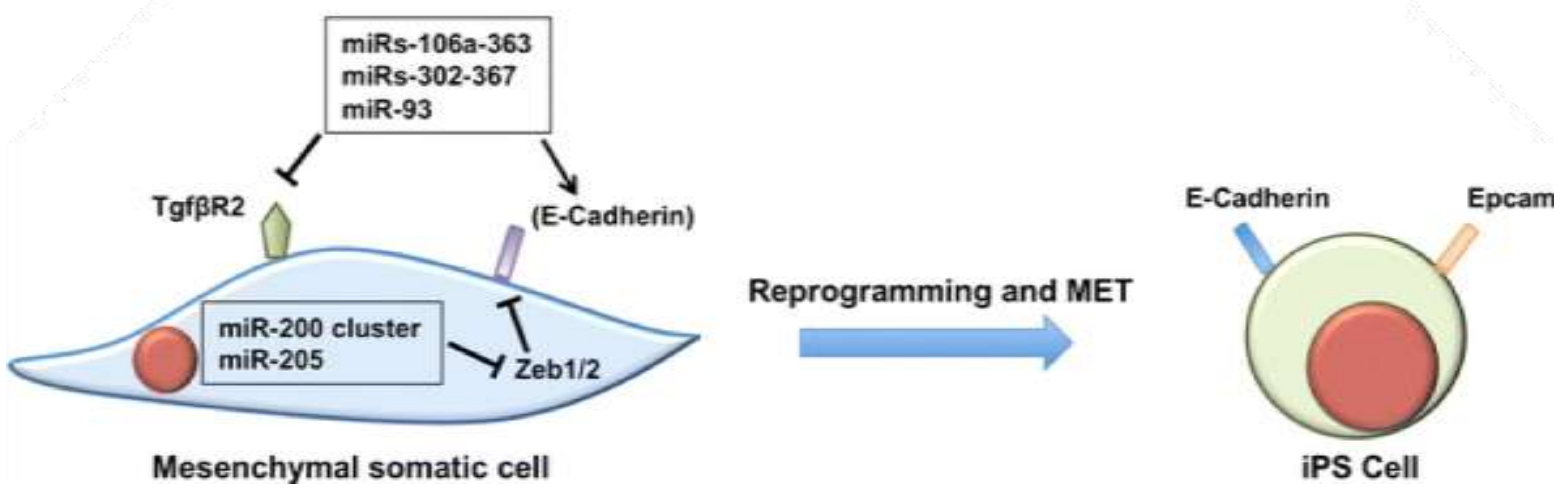

Figure 4.7. Schematic representation of miRNAs functions in the process of mesenchymal-to-epithelial transition. The members of miR-106 363, miR-302 cluster and miR-93 (member of miR-106b 25 cluster) repress Tgf $\beta$ receptor and inhibit anti-epithelial stimuli. Further, members of miR-106 363 and miR-302 clusters facilitate the expression of epithelial marker E-Cadherin. In addition, member of miR-200 cluster together with miR-205 repress the E-Cadherin antagonists Zebl/2 (figure adopted from Pfaff et al., 2012).

\subsection{Function of miRNAs in gametogenesis}

In sexually reproducing organisms, gametes are the only cells capable of transmitting genetic information to the next generation. Many transcriptional as well as posttranscriptional mechanisms have been reported to regulate the process of gametogenesis (Pangas and Rajkovic, 2006; Bettegowda and Wilkinson, 2010). One of the recently discovered mechanisms governing gametogenesis includes miRNAs (Tang et al., 2007; Meng et al., 
2011). By taking advantage of conditional knockout mouse models, many research groups have proven the importance of miRNAs in gametogenesis. The loss of total miRNA caused by depletion of Drosha or Dicer specifically in PGCs or spermatogonia resulted in male infertility (Hayashi et al., 2008; Maatouk et al., 2008; Korhonen et al., 2011; Wu et al., 2012). Similarly, lack of Dicer in mouse oocytes resulted in female infertility (Murchison et al., 2007). Surprisingly, depletion of $\operatorname{Dgcr} 8$ in oocytes did not affect female fertility (Suh et al., 2010). Moreover $\mathrm{Dgcr}^{-/}$oocytes can be fertilized by wild type sperm and the resulting zygotes develop and give rise to healthy pups (Suh et al., 2010). These results are in contradiction with previous reports and led to a suggestion that phenotypes observed in Dicer $^{-/-}$females and zygotes are probably caused by a lack of endogenous small interfering RNAs (siRNAs) rather than miRNAs (Tang et al., 2007; Ma et al., 2010). In line with these assumptions, importance of endogenous siRNA, generated by Dicer, was reported in the regulation of gene expression in mouse oocytes (Tam et al., 2008; Watanabe et al., 2008). Taken together, miRNAs seems to have uneven contribution to gametes formation in male and female.

\subsubsection{Functions of miRNAs in the process of spermatogenesis}

Spermatogenesis is a process common for all sexually reproducing animals through mitotic proliferation, meiotic divisions and maturation phases to finally give rise to functional sperm (Cooke and Saunders, 2002). Spermatogonial stem cells (SSCs), the unipotent stem cells, assure the source for generation of male gametes. In an attempt to identify miRNAs with a function in spermatogenesis, many research groups have characterized miRNA expression profiles of various germ cell populations or testicular cells isolated form prepubertal and adult animals (Yu et al., 2005; Ro et al., 2007; Yan et al., 2007; Song et al., 2009). In the present study (Smorag et al., 2012), we developed an efficient system for isolation of SSCs, pre-meiotic (PrM) and meiotic cells. Generation of double transgenic mouse model (Stra8/EGFP and Sycp3/DsRed) led us to isolate pre-meiotic spermatogonia (green) and primary spermatocytes (red) using FACS approach. Comparison of miRNA profiles between SSCs, PrM and meiotic cells led us to identify miRNAs specific for only one, two or all three cell types. Through our study, for the first time, dynamic changes in miRNAs expression during spermatogenesis can be shown. In agreement with recent studies, we identified many miRNAs expressed in a stage-specific manner (Yu et al., 2005; Yan et al., 2007; Song et al., 2009; Buchold et al., 2010; Niu et al., 2011). Our results indicate that 
miR-221, 203 and miR-34b-5p play an important role in spermatogenesis regulation by targeting $c$-Kit, Rbm44 and Cdk6 genes, respectively. Interestingly $\mathrm{Kit}^{\mathrm{W} / \mathrm{W}}, \mathrm{Cdk6}^{-/}$as well as its downstream target, $C d k 2^{-/}$mice are subfertile or infertile (Yoshinaga et al., 1991; Ortega et al., 2003; Malumbres et al., 2004). Our knowledge about miRNA in later stages of spermatogenesis is rather poor and mostly based on analysis of miRNA profiles from whole testis. Till now only miR-122a and miRNA-34c were characterized in spermatids (Yu et al., 2005; Liang et al., 2012). miR-122a has been reported to regulate histone-protamine exchange by targeting transition protein 2 (Tnp2) (Yu et al., 2005). However Tnp $2^{-/}$animals were fertile, although they show abnormalities during chromatin condensation in spermatids (Zhao et al., 2001). Similarly, miR-34c has been shown to regulate apoptosis by targeting Atfl gene (Liang et al., 2012). Atf1 has been reported to maintain cell viability during embryo development, however its function in germ cells is unknown (Bleckmann et al., 2002). Interestingly, miRNA-34c was also detected in mature sperm and is known to regulate first cleavage division of the mouse zygote after fertilization. (Liu et al., 2011). These results highlighted that sperm contributes more than just a delivery of paternal genome during zygote development. Functions of miRNAs during spermatogenesis and early embryonic development are summarized in Figure. 4.8.

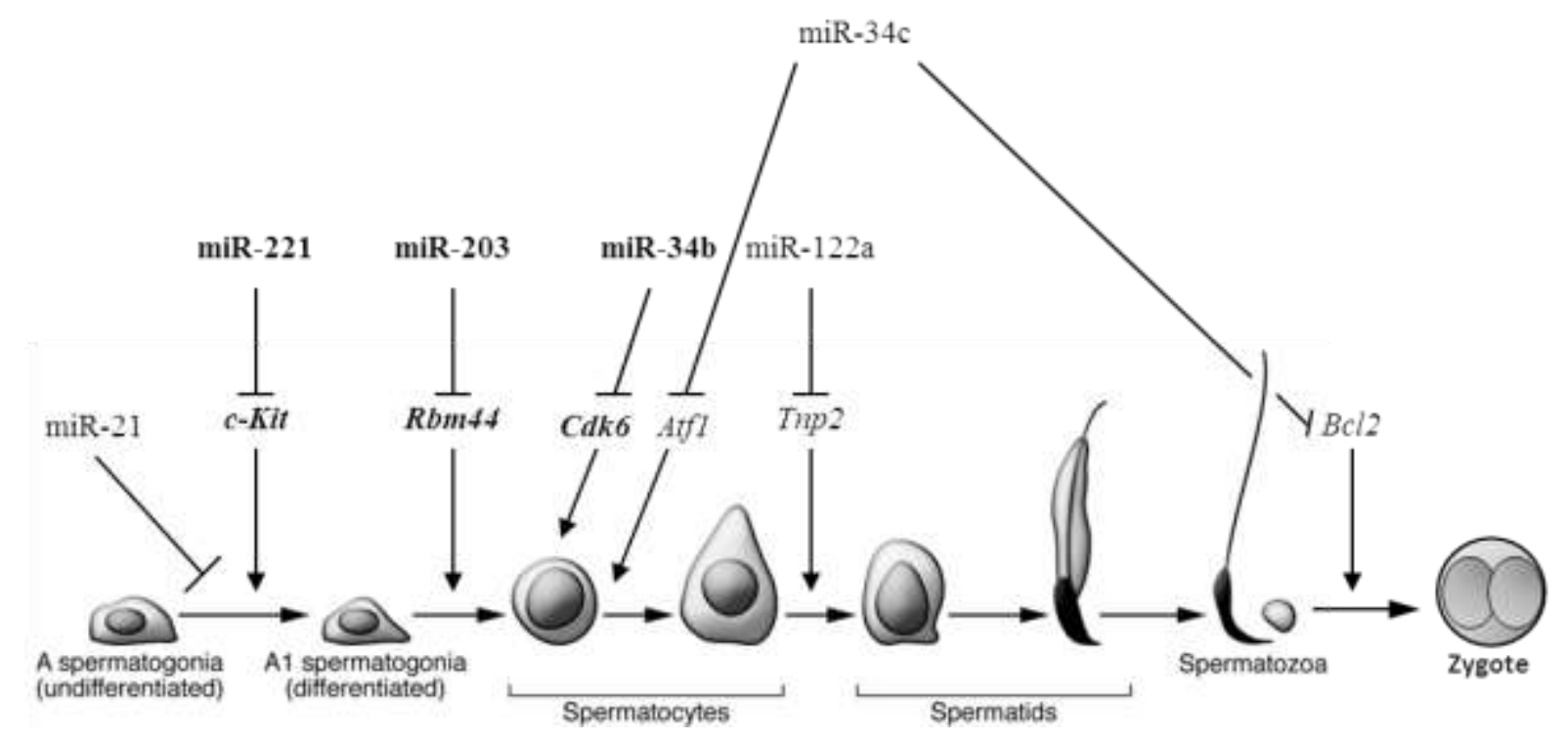

Figure 4.8. Working model for the function of miRNAs during spermatogenesis. Spatiotemporal expression of miRNAs regulates sequential steps of male germ cells maturation. miRNAs along with their corresponding targets, which were identified in the present study, are indicated in bold (Smorag et al., 2012) (figure adopted and modified from Hogarth and Griswold, 2010). 


\section{5. miRNAs and human diseases}

Growing body of evidence suggests that miRNAs play a crucial role in health and disease. According to miRNA-disease data base in the year 2010, there are 174 described diseases associated with dys-regulated expression of miRNAs (www.mir2disease.org) (Jiang et al., 2009). Interestingly, 83 out of 174 diseases are cancer-related diseases. Due to relatively small size of mature miRNA sequences and their corresponding binding motifs in 3'-UTR of target genes, diseases caused by direct mutation in these regions are extremely rare. Till now, there is only one evidence for each case of mutation in miRNA and its target sequence. Point mutation (substitution of $A$ to $G$ ) in the seed sequence of miRNA-96 was reported to result in hearing loss (Mencia et al., 2009), while disruption of miRNA-189 binding site caused by substitution of G to A in 3'-UTR of SLITRK1 was described as responsible for Tourette's syndrome (Abelson et al., 2005). Since a single miRNA can regulate many targets and vice versa a single target can be regulated by several miRNAs, phenotype due to mutations occurring in either miRNAs sequence or their binding sites can be obscured by compensation mechanisms. This hypothesis can explain why diseases caused by mutations in the most abundant RNA family are so rare.

\section{6. miRNAs as therapeutic drugs}

Recent advances in understanding the function of miRNAs have led to use these small RNA molecules as a therapeutic drug. In theory, suppression of particular miRNA linked to disease might eliminate the block against the expression of corresponding therapeutic protein and conversely, delivery of mimic miRNAs can repress the expression of harmful gene. Although this new branch of pharmacology is quite attractive, the multiple functions of a single miRNA must be taken into consideration before any attempts of therapeutic usage. The data presented by Pharmaprojects (online data base of advances in pharmacological technology) summarizes the status of miRNA therapeutic approaches (Table 4.1.). The first ever miRNA-based therapy against Hepatitis $\mathrm{C}$ virus (HCV) is already in second phase of clinical trials. Collectively, the current pace of miRNA research holds great promise for future development of novel miRNA-based therapeutics. 
Discussion

\begin{tabular}{|c|c|c|c|c|c|}
\hline Generic name & Originator & Status & Pharmacology & Target & Aplication \\
\hline SPC-3649 & Santaris Pharma & Phase II & miRNA Inhibitor & miRNA-122 & $\begin{array}{c}\text { Infection, } \mathrm{HCV}, \\
\text { Hypercholesterolemia }\end{array}$ \\
\hline $\begin{array}{l}\text { anti-miR-122 } \\
\text { oligo, Regulus }\end{array}$ & Alnylam & Preclinical & miRNA Inhibitor & miRNA-122 & Infection, $\mathrm{HCV}$ \\
\hline $\begin{array}{c}\text { miRNA } \\
\text { inhibitors, } \\
\text { Miragen }\end{array}$ & $\begin{array}{c}\text { Miragen } \\
\text { Therapeutics }\end{array}$ & Preclinical & miRNA Inhibitor & miRNA-208a & Heart failure \\
\hline $\begin{array}{c}\text { miRNA } \\
\text { mimetics, } \\
\text { Miragen }\end{array}$ & $\begin{array}{c}\text { Miragen } \\
\text { Therapeutics }\end{array}$ & Preclinical & miRNA stimulant & Unspecific & Heart failure \\
\hline $\begin{array}{l}\text { prostate cancer } \\
\text { miRNAs, Mirna }\end{array}$ & $\begin{array}{c}\text { Mirna } \\
\text { Therapeutics }\end{array}$ & Preclinical & miRNA stimulant & Unspecific & Cancer, prostate \\
\hline $\begin{array}{l}\text { AML miRNA } \\
\text { therapy, Mirna }\end{array}$ & $\begin{array}{c}\text { Mirna } \\
\text { Therapeutics }\end{array}$ & Preclinical & miRNA stimulant & Unspecific & $\begin{array}{l}\text { Cancer, leukaemia, } \\
\text { acute myelogenous }\end{array}$ \\
\hline $\begin{array}{l}\text { nsclc miRNA } \\
\text { therapy, Mirna }\end{array}$ & $\begin{array}{c}\text { Mirna } \\
\text { Therapeutics }\end{array}$ & Preclinical & miRNA stimulant & $\begin{array}{l}\text { microRNA let- } \\
7 \mathrm{a}-1\end{array}$ & $\begin{array}{l}\text { Cancer, lung, non- } \\
\text { small cell }\end{array}$ \\
\hline $\begin{array}{l}\text { herpes virus } \\
\text { therapy, Rosetta }\end{array}$ & $\begin{array}{c}\text { Rosetta } \\
\text { Genomics }\end{array}$ & Preclinical & miRNA Inhibitor & Unspecific & $\begin{array}{l}\text { Infection, Epstein- } \\
\text { Barr virus, herpes } \\
\text { simplex virus }\end{array}$ \\
\hline $\begin{array}{l}\text { miR-34a } \\
\text { mimetics, } \\
\text { Rosetta }\end{array}$ & $\begin{array}{c}\text { Rosetta } \\
\text { Genomics }\end{array}$ & Preclinical & $\begin{array}{l}\text { miRNA stimulant } \\
\text { p53 stimulant } \\
\text { Apoptosis agonist }\end{array}$ & $\begin{array}{l}\text { miRNA-34a } \\
\text { tumor protein } \\
\text { p53 }\end{array}$ & Cancer, liver \\
\hline $\begin{array}{c}\text { hepatitis C } \\
\text { therapy, Rosseta }\end{array}$ & $\begin{array}{c}\text { Rosetta } \\
\text { Genomics }\end{array}$ & Preclinical & miRNA Inhibitor & Unspecific & Infection, $\mathrm{HCV}$ \\
\hline $\begin{array}{c}\text { HIV therapy, } \\
\text { Rosseta }\end{array}$ & $\begin{array}{c}\text { Rosetta } \\
\text { Genomics }\end{array}$ & Preclinical & miRNA Inhibitor & Unspecific & Infection, HIV/AIDS \\
\hline
\end{tabular}

Table 4.1. List of miRNA-based therapeutics which are in clinical and preclinical trials (table adapted and modified from http://www.pharmaprojects.com)

\subsection{Identification and characterization of novel meiotic genes}

Meiosis is the crucial process occurring during gametogenesis, leading to formation of haploid germ cells. However, our knowledge regarding meiotic processes is limited owing to only a few genes involved in this process. In order to identify new germ cells specific markers including meiotic genes, many research groups have performed transcriptome analysis of purified germ cells (Pang et al., 2003; Yu et al., 2003; Ma et al., 2012). Although these studies were able to identify genes specific for germ cells, no functional characterization of identified genes was done. In the present study, we took advantage of our double transgenic mouse model (Stra8/EGFP, Sycp3/DsRed) to identify and to characterize 
novel meiotic-specific genes. After isolation and characterization of pre-meiotic and meiotic cells from double transgenic mouse testis using FACS, we performed mRNA expression profiling using Agilent Technologies 44K Mouse Whole Genome Microarray. Hierarchical clustering of transcriptome results revealed distant clustering of pre-meiotic (green cells) and meiotic (red cells) cells, while their biological replicates were closely related (Fig. 4.9A). Then, we applied a stringent selection criterion that is 7-fold expression difference between green and red cells to identify meiotic-specific genes. This analysis led us to identify 31 genes as pre-meiotic specific, while 142 genes were identified as meiotic-specific (Fig. 4.9B.). Further, we selected 10 meiotic-specific candidate genes (named as Meio1-10) with unknown function, for further characterization. The selected candidates displayed highest expression in red cells compared to green cells, and have been reported as testis-specific with unknown function in gene expression data base (www.ebi.ac.uk/gxa/). RT-PCR analysis confirmed the expression of nine of them in testis, while Meio4 could not be amplified by RT-PCR (Fig. 4.10). To confirm the testis specific expression of these novel Meio genes, we analyzed their expression in various adult mouse tissues. Seven out of nine Meio genes displayed testis-specific expression (Fig. 4.11). Meio2 and Meio6 showed ubiquitous expression and were excluded from further characterization. Next, we confirmed that none of these testis-specific Meio genes are expressed in $\mathrm{Kit}^{\mathrm{W} / \mathrm{Wv}}$ mouse testis (data not shown) indicating the germ cell-specificity. We checked the expression of these seven Meio genes during different mouse testicular developmental stages i.e. 5dpp till 20dpp (Fig. 4.12.). Apart from Meio3, all other Meio genes expression was first detected around day 15 (Fig. 4.12.), which correlates well with the appearance of primary spermatocytes in mouse testicular development. Taken together, these results led us to identify six novel meiosis-specific genes. The results of Meio genes expression analysis are summarized in Table 4.2. Further characterization of these selected Meio genes might help us to better understand their function in meiosis as well as to strengthen our knowledge about meiosis regulation. 
A.

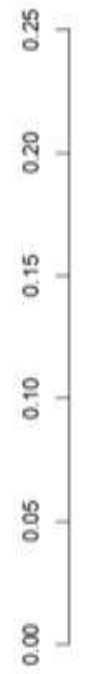

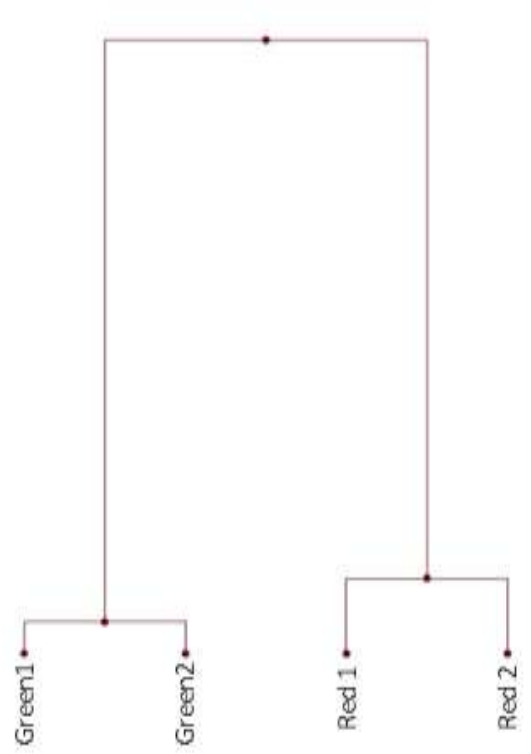

B.

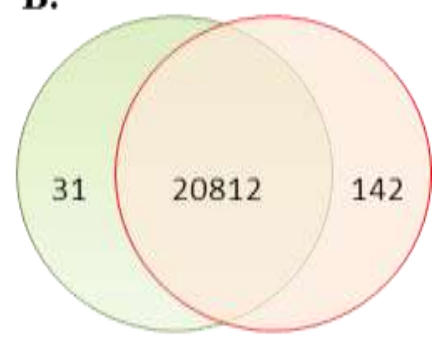

Figure 4.9. Transcriptome analysis of pre-meiotic (green) and meiotic (red) cells isolated from Stra8/EGFP and Sycp3/DsRed transgenic mouse testis. (A) Hierarchical clustering of transcriptome data. (B) Venn diagram illustrating number of green and red-specific genes.

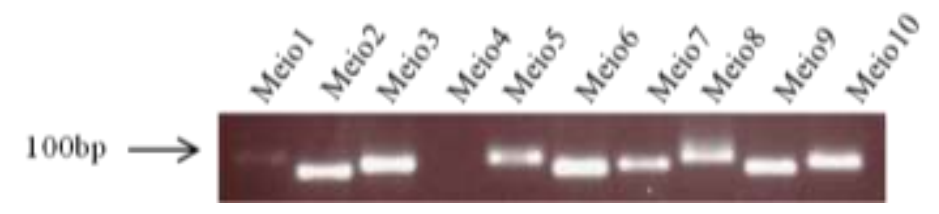

Figure. 4.10. Expression analysis of Meio1-10 genes in mouse testis. RT-PCR analysis for Meio1-10 genes expression in adult mouse testis.

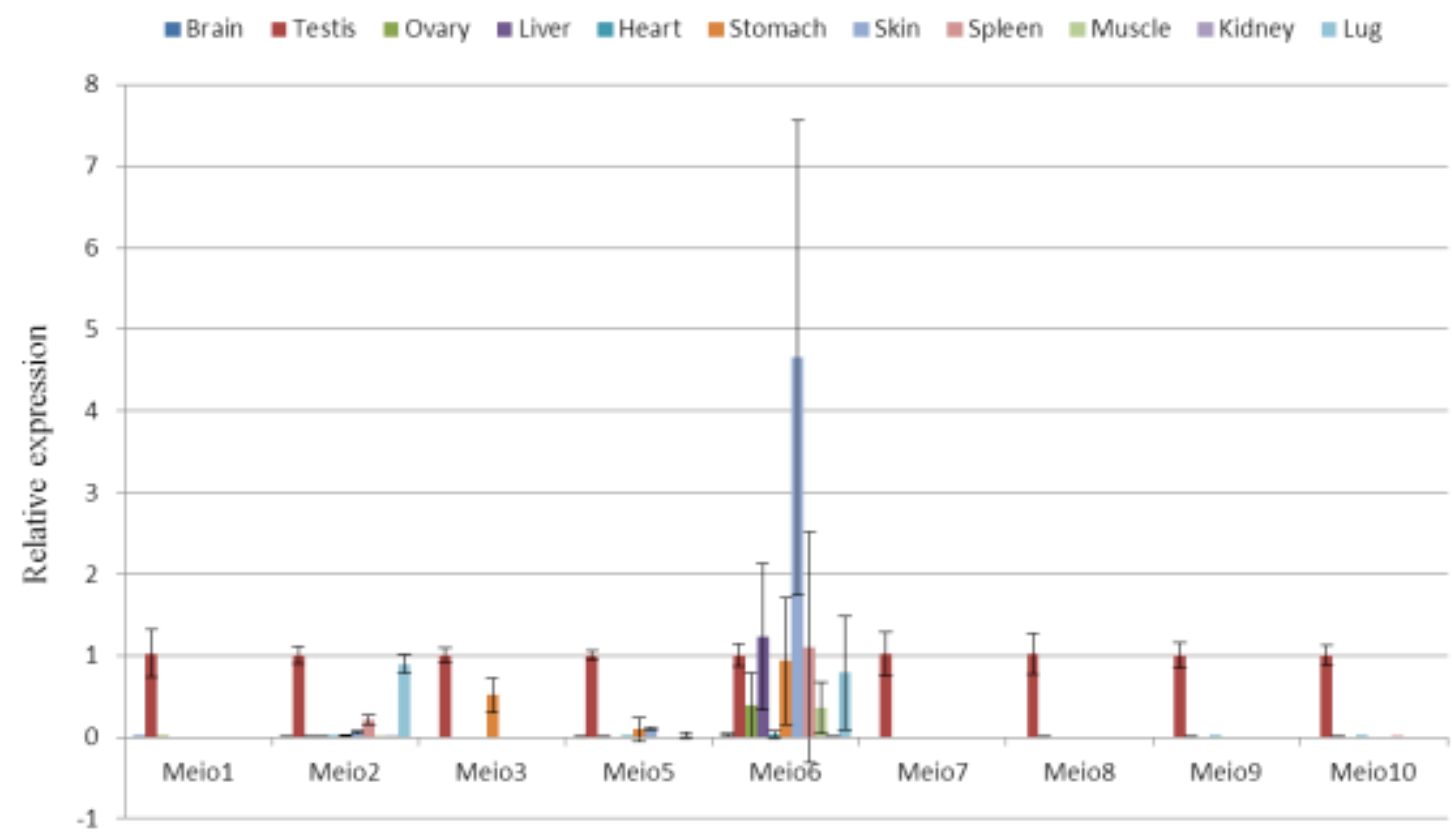

Figure 4.11. Expression analysis of novel Meio genes in different adult mouse tissues. Bar graph showing the expression levels of Meio genes in adult mouse tissues (combined qRT-PCR data of male and female tissues were normalized against testis expression). 


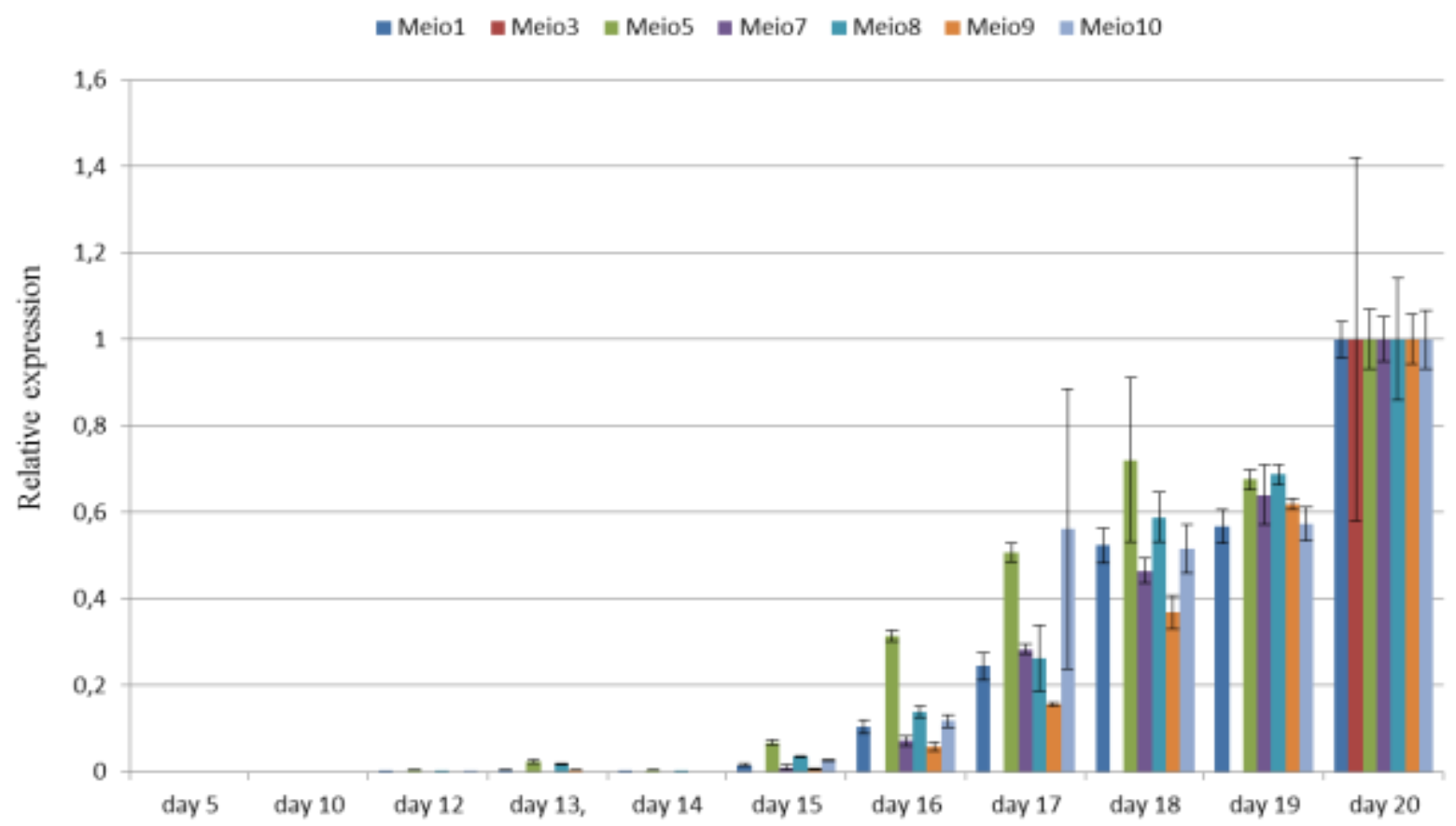

Figure 4.12. Expression analysis of novel Meio genes during mouse testis development. Bar graph showing the expression of Meio genes at various testicular developmental stages.

\begin{tabular}{|c|c|c|c|c|c|}
\hline Name & Symbol & $\begin{array}{c}\text { Testis } \\
\text { expression }\end{array}$ & $\begin{array}{c}\text { Testis } \\
\text { specificity }\end{array}$ & $\begin{array}{c}\text { Meiotic } \\
\text { character }\end{array}$ & $\begin{array}{c}\text { Absence in } \\
\text { W/Wv }\end{array}$ \\
\hline 1700017D01Rik & Meio1 & $\checkmark$ & $\checkmark$ & $\checkmark$ & $\checkmark$ \\
\hline Pom12112 & Meio2 & $\checkmark$ & X & n/a & n/a \\
\hline 1700017G19Rik & Meio3 & $\checkmark$ & $\checkmark$ & X & n/a \\
\hline 4933415F23Rik & Meio4 & X & n/a & $\checkmark$ & $\checkmark$ \\
\hline Poteg & Meio5 & $\checkmark$ & $\checkmark$ & n/a & n/a \\
\hline Abca15 & Meio6 & $\checkmark$ & X & $\checkmark$ & $\checkmark$ \\
\hline 4933409D19Rik & Meio7 & $\checkmark$ & $\checkmark$ & $\checkmark$ & $\checkmark$ \\
\hline Fam170a & Meio8 & $\checkmark$ & $\checkmark$ & $\checkmark$ & $\checkmark$ \\
\hline 1700008F21Rik & Meio9 & $\checkmark$ & $\checkmark$ & $\checkmark$ & $\checkmark$ \\
\hline 4930403N07Rik & Meio10 & $\checkmark$ & $\checkmark$ & \\
\hline
\end{tabular}

Table 4.2 Characterization of novel meiotic-specific genes. The first column displays the official name of Meio genes followed by name given in the present study. V-indicates positive results, $\mathrm{X}$-negative results and N/A - not analyzed. 


\subsection{Future endeavors and perspectives}

In the present study, we identified two novel pluripotent cell-specific miRNAs (miR135b and miR-363) and their targets (Ccng2 and Nox4, respectively). Further studies using stable overexpression and downregulation of these miRNAs and their role during differentiation of ESCs would shed light on their function in pluripotent cells. Moreover, the functional characterization of their target genes Ccng2 and Nox4 during differentiation would help us to understand the differentiation potential of ESCs. It is interesting to note that miR$135 \mathrm{~b}$ overexpression was reported in several cancer cell types. In line with these observations, our preliminary results also showed an overexpression of miR-135b in one prostate and two colorectal cancer cell lines. Hence, studies on how miR-135b is involved in cell cycle regulation of cancer cells as well as of pluripotent stem cells would help us to dissect the mechanism of cell cycle regulation in these cells. It is also interesting to test whether miR-135b can initiate the tumorgenesis. Additionally, generation of loss-of-function and gain-of-function mouse models will help us to understand their function during development.

The identification of stage-specific miRNAs during the process of spermatogenesis indicates the spatiotemporal control of this process by miRNAs. Interestingly, our in silico analysis indicated the presence of these stage-specific miRNAs in human genome, thus highlighting their possible conserved role in spermatogenesis. Further studies aimed at generation of loss-of-function mouse models and analysis of their phenotypes would help us to identify the functional significance of these miRNAs. The knowledge obtained through these mouse models might help us to identify the potential cause of infertility in idiopathic patients and development of possible therapies.

The transcriptome analysis of pre-meiotic and meiotic cells led us to identify several meiosis-specific genes with unknown functions. The identification of protein interaction partners of these novel genes and their functional characterization might help us to understand their physiological function during meiosis. Furthermore, generation of antibodies against protein products of these novel meiotic genes would facilitate cellular, molecular and biochemical studies. The higher expression of these genes in meiotic cells led us to speculate that the overexpression of these genes in pluripotent cells might result in successful progression of meiosis and thereby the generation of haploid gametes. Finally, the generation of knockout and transgenic mouse models for these genes will uncover their function during gametogenesis. 


\section{References}

Abelson, J.F., Kwan, K.Y., O'Roak, B.J., Baek, D.Y., Stillman, A.A., Morgan, T.M., Mathews, C.A., Pauls, D.L., Rasin, M.R., Gunel, M., Davis, N.R., Ercan-Sencicek, A.G., Guez, D.H., Spertus, J.A., Leckman, J.F., Dure, L.S.t., Kurlan, R., Singer, H.S., Gilbert, D.L., Farhi, A., Louvi, A., Lifton, R.P., Sestan, N., and State, M.W. (2005). Sequence variants in SLITRK1 are associated with Tourette's syndrome. Science 310, 317-320.

Alisch, R.S., Jin, P., Epstein, M., Caspary, T., and Warren, S.T. (2007). Argonaute2 is essential for mammalian gastrulation and proper mesoderm formation. PLoS Genet 3, e227.

Ambros, V. (2004). The functions of animal microRNAs. Nature 431, 350-355.

Ambros, V., Bartel, B., Bartel, D.P., Burge, C.B., Carrington, J.C., Chen, X., Dreyfuss, G., Eddy, S.R., Griffiths-Jones, S., Marshall, M., Matzke, M., Ruvkun, G., and Tuschl, T. (2003). A uniform system for microRNA annotation. RNA 9, 277-279.

Ambros, V., and Horvitz, H.R. (1984). Heterochronic mutants of the nematode Caenorhabditis elegans. Science 226, 409-416.

Anokye-Danso, F., Trivedi, C.M., Juhr, D., Gupta, M., Cui, Z., Tian, Y., Zhang, Y., Yang, W., Gruber, P.J., Epstein, J.A., and Morrisey, E.E. (2011). Highly efficient miRNAmediated reprogramming of mouse and human somatic cells to pluripotency. Cell Stem Cell 8, 376-388.

Barad, O., Meiri, E., Avniel, A., Aharonov, R., Barzilai, A., Bentwich, I., Einav, U., Gilad, S., Hurban, P., Karov, Y., Lobenhofer, E.K., Sharon, E., Shiboleth, Y.M., Shtutman, M., Bentwich, Z., and Einat, P. (2004). MicroRNA expression detected by oligonucleotide microarrays: system establishment and expression profiling in human tissues. Genome Res 14, 2486-2494.

Bartel, D.P. (2004). MicroRNAs: genomics, biogenesis, mechanism, and function. Cell 116, 281-297.

Benetti, R., Gonzalo, S., Jaco, I., Munoz, P., Gonzalez, S., Schoeftner, S., Murchison, E., Andl, T., Chen, T., Klatt, P., Li, E., Serrano, M., Millar, S., Hannon, G., and Blasco, M.A. (2008). A mammalian microRNA cluster controls DNA methylation and telomere recombination via Rbl2-dependent regulation of DNA methyltransferases. Nat Struct Mol Biol 15, 998. 
Bernstein, E., Kim, S.Y., Carmell, M.A., Murchison, E.P., Alcorn, H., Li, M.Z., Mills, A.A., Elledge, S.J., Anderson, K.V., and Hannon, G.J. (2003). Dicer is essential for mouse development. Nat Genet 35, 215-217.

Bettegowda, A., and Wilkinson, M.F. (2010). Transcription and post-transcriptional regulation of spermatogenesis. Philos Trans R Soc Lond B Biol Sci 365, 1637-1651.

Bleckmann, S.C., Blendy, J.A., Rudolph, D., Monaghan, A.P., Schmid, W., and Schutz, G. (2002). Activating transcription factor 1 and CREB are important for cell survival during early mouse development. Mol Cell Biol 22, 1919-1925.

Boominathan, L. (2010). The tumor suppressors p53, p63, and p73 are regulators of microRNA processing complex. PLoS One 5, e10615.

Bradley, A., Evans, M., Kaufman, M.H., and Robertson, E. (1984). Formation of germ-line chimaeras from embryo-derived teratocarcinoma cell lines. Nature 309, 255-256.

Buchold, G.M., Coarfa, C., Kim, J., Milosavljevic, A., Gunaratne, P.H., and Matzuk, M.M. (2010). Analysis of microRNA expression in the prepubertal testis. PLoS One 5, e15317.

Burdon, T., Smith, A., and Savatier, P. (2002). Signalling, cell cycle and pluripotency in embryonic stem cells. Trends Cell Biol 12, 432-438.

Cai, X., Hagedorn, C.H., and Cullen, B.R. (2004). Human microRNAs are processed from capped, polyadenylated transcripts that can also function as mRNAs. RNA 10, $1957-$ 1966.

Card, D.A., Hebbar, P.B., Li, L., Trotter, K.W., Komatsu, Y., Mishina, Y., and Archer, T.K. (2008). Oct4/Sox2-regulated miR-302 targets cyclin D1 in human embryonic stem cells. Mol Cell Biol 28, 6426-6438.

Chalfie, M., Horvitz, H.R., and Sulston, J.E. (1981). Mutations that lead to reiterations in the cell lineages of C. elegans. Cell 24, 59-69.

Chen, X., Xu, H., Yuan, P., Fang, F., Huss, M., Vega, V.B., Wong, E., Orlov, Y.L., Zhang, W., Jiang, J., Loh, Y.H., Yeo, H.C., Yeo, Z.X., Narang, V., Govindarajan, K.R., Leong, B., Shahab, A., Ruan, Y., Bourque, G., Sung, W.K., Clarke, N.D., Wei, C.L., and Ng, H.H. (2008). Integration of external signaling pathways with the core transcriptional network in embryonic stem cells. Cell 133, 1106-1117.

Chin, M.H., Mason, M.J., Xie, W., Volinia, S., Singer, M., Peterson, C., Ambartsumyan, G., Aimiuwu, O., Richter, L., Zhang, J., Khvorostov, I., Ott, V., Grunstein, M., Lavon, N., Benvenisty, N., Croce, C.M., Clark, A.T., Baxter, T., Pyle, A.D., Teitell, M.A., Pelegrini, M., Plath, K., and Lowry, W.E. (2009). Induced pluripotent stem cells and 
embryonic stem cells are distinguished by gene expression signatures. Cell Stem Cell 5, 111-123.

Cooke, H.J., and Saunders, P.T. (2002). Mouse models of male infertility. Nat Rev Genet 3, 790-801.

Creighton, C.J., Reid, J.G., and Gunaratne, P.H. (2009). Expression profiling of microRNAs by deep sequencing. Brief Bioinform 10, 490-497.

Davis, B.N., Hilyard, A.C., Lagna, G., and Hata, A. (2008). SMAD proteins control DROSHA-mediated microRNA maturation. Nature 454, 56-61.

Denli, A.M., Tops, B.B., Plasterk, R.H., Ketting, R.F., and Hannon, G.J. (2004). Processing of primary microRNAs by the Microprocessor complex. Nature 432, 231-235.

Doench, J.G., and Sharp, P.A. (2004). Specificity of microRNA target selection in translational repression. Genes Dev 18, 504-511.

Eddy, S.R. (2001). Non-coding RNA genes and the modern RNA world. Nat Rev Genet 2, 919-929.

Evans, M.J., and Kaufman, M.H. (1981). Establishment in culture of pluripotential cells from mouse embryos. Nature 292, 154-156.

Friedman, R.C., Farh, K.K., Burge, C.B., and Bartel, D.P. (2009). Most mammalian mRNAs are conserved targets of microRNAs. Genome Res 19, 92-105.

Gregory, P.A., Bert, A.G., Paterson, E.L., Barry, S.C., Tsykin, A., Farshid, G., Vadas, M.A., Khew-Goodall, Y., and Goodall, G.J. (2008). The miR-200 family and miR-205 regulate epithelial to mesenchymal transition by targeting ZEB1 and SIP1. Nat Cell Biol 10, 593-601.

Gregory, P.A., Bracken, C.P., Smith, E., Bert, A.G., Wright, J.A., Roslan, S., Morris, M., Wyatt, L., Farshid, G., Lim, Y.Y., Lindeman, G.J., Shannon, M.F., Drew, P.A., KhewGoodall, Y., and Goodall, G.J. (2011). An autocrine TGF-beta/ZEB/miR-200 signaling network regulates establishment and maintenance of epithelial-mesenchymal transition. Mol Biol Cell 22, 1686-1698.

Griffiths-Jones, S. (2004). The microRNA Registry. Nucleic Acids Res 32, D109-111.

Grishok, A., Pasquinelli, A.E., Conte, D., Li, N., Parrish, S., Ha, I., Baillie, D.L., Fire, A., Ruvkun, G., and Mello, C.C. (2001). Genes and mechanisms related to RNA interference regulate expression of the small temporal RNAs that control C. elegans developmental timing. Cell 106, 23-34. 
Haase, A.D., Jaskiewicz, L., Zhang, H., Laine, S., Sack, R., Gatignol, A., and Filipowicz, W. (2005). TRBP, a regulator of cellular PKR and HIV-1 virus expression, interacts with Dicer and functions in RNA silencing. EMBO Rep 6, 961-967.

Han, J., Lee, Y., Yeom, K.H., Kim, Y.K., Jin, H., and Kim, V.N. (2004). The DroshaDGCR8 complex in primary microRNA processing. Genes Dev 18, 3016-3027.

Han, J., Lee, Y., Yeom, K.H., Nam, J.W., Heo, I., Rhee, J.K., Sohn, S.Y., Cho, Y., Zhang, B.T., and Kim, V.N. (2006). Molecular basis for the recognition of primary microRNAs by the Drosha-DGCR8 complex. Cell 125, 887-901.

Harper, J.W., Adami, G.R., Wei, N., Keyomarsi, K., and Elledge, S.J. (1993). The p21 Cdkinteracting protein $\mathrm{Cip} 1$ is a potent inhibitor of G1 cyclin-dependent kinases. Cell 75, 805-816.

Hayashi, K., Chuva de Sousa Lopes, S.M., Kaneda, M., Tang, F., Hajkova, P., Lao, K., O'Carroll, D., Das, P.P., Tarakhovsky, A., Miska, E.A., and Surani, M.A. (2008). MicroRNA biogenesis is required for mouse primordial germ cell development and spermatogenesis. PLoS One 3, e1738.

He, L., and Hannon, G.J. (2004). MicroRNAs: small RNAs with a big role in gene regulation. Nat Rev Genet 5, 522-531.

Hogarth, C.A., and Griswold, M.D. (2010). The key role of vitamin A in spermatogenesis. J Clin Invest 120, 956-962.

Houbaviy, H.B., Murray, M.F., and Sharp, P.A. (2003). Embryonic stem cell-specific MicroRNAs. Dev Cell 5, 351-358.

Hutvagner, G., McLachlan, J., Pasquinelli, A.E., Balint, E., Tuschl, T., and Zamore, P.D. (2001). A cellular function for the RNA-interference enzyme Dicer in the maturation of the let-7 small temporal RNA. Science 293, 834-838.

Jiang, Q., Wang, Y., Hao, Y., Juan, L., Teng, M., Zhang, X., Li, M., Wang, G., and Liu, Y. (2009). miR2Disease: a manually curated database for microRNA deregulation in human disease. Nucleic Acids Res 37, D98-104.

Judson, R.L., Babiarz, J.E., Venere, M., and Blelloch, R. (2009). Embryonic stem cellspecific microRNAs promote induced pluripotency. Nat Biotechnol 27, 459-461.

Kanellopoulou, C., Muljo, S.A., Kung, A.L., Ganesan, S., Drapkin, R., Jenuwein, T., Livingston, D.M., and Rajewsky, K. (2005). Dicer-deficient mouse embryonic stem cells are defective in differentiation and centromeric silencing. Genes Dev 19, 489-501.

Kato, J. (1999). Induction of S phase by G1 regulatory factors. Front Biosci 4, D787-792. 
Ketting, R.F., Fischer, S.E., Bernstein, E., Sijen, T., Hannon, G.J., and Plasterk, R.H. (2001). Dicer functions in RNA interference and in synthesis of small RNA involved in developmental timing in C. elegans. Genes Dev 15, 2654-2659.

Kong, Y.W., Ferland-McCollough, D., Jackson, T.J., and Bushell, M. (2012). microRNAs in cancer management. Lancet Oncol 13, e249-258.

Korhonen, H.M., Meikar, O., Yadav, R.P., Papaioannou, M.D., Romero, Y., Da Ros, M., Herrera, P.L., Toppari, J., Nef, S., and Kotaja, N. (2011). Dicer is required for haploid male germ cell differentiation in mice. PLoS One 6, e24821.

Krol, J., Loedige, I., and Filipowicz, W. (2010). The widespread regulation of microRNA biogenesis, function and decay. Nat Rev Genet 11, 597-610.

Kuo, C.H., and Ying, S.Y. (2012). Advances in microRNA-mediated reprogramming technology. Stem Cells Int 2012, 823709.

Lagos-Quintana, M., Rauhut, R., Lendeckel, W., and Tuschl, T. (2001). Identification of novel genes coding for small expressed RNAs. Science 294, 853-858.

Lagos-Quintana, M., Rauhut, R., Yalcin, A., Meyer, J., Lendeckel, W., and Tuschl, T. (2002). Identification of tissue-specific microRNAs from mouse. Curr Biol 12, 735-739.

Lakshmipathy, U., Love, B., Goff, L.A., Jornsten, R., Graichen, R., Hart, R.P., and Chesnut, J.D. (2007). MicroRNA expression pattern of undifferentiated and differentiated human embryonic stem cells. Stem Cells Dev 16, 1003-1016.

Lau, N.C., Lim, L.P., Weinstein, E.G., and Bartel, D.P. (2001). An abundant class of tiny RNAs with probable regulatory roles in Caenorhabditis elegans. Science 294, 858-862.

Lee, R.C., and Ambros, V. (2001). An extensive class of small RNAs in Caenorhabditis elegans. Science 294, 862-864.

Lee, R.C., Feinbaum, R.L., and Ambros, V. (1993). The C. elegans heterochronic gene lin-4 encodes small RNAs with antisense complementarity to lin-14. Cell 75, 843-854.

Lee, Y., Ahn, C., Han, J., Choi, H., Kim, J., Yim, J., Lee, J., Provost, P., Radmark, O., Kim, S., and Kim, V.N. (2003). The nuclear RNase III Drosha initiates microRNA processing. Nature 425, 415-419.

Lee, Y., Kim, M., Han, J., Yeom, K.H., Lee, S., Baek, S.H., and Kim, V.N. (2004). MicroRNA genes are transcribed by RNA polymerase II. EMBO J 23, 4051-4060.

Lewis, B.P., Burge, C.B., and Bartel, D.P. (2005). Conserved seed pairing, often flanked by adenosines, indicates that thousands of human genes are microRNA targets. Cell 120, $15-20$. 
Li, R., Liang, J., Ni, S., Zhou, T., Qing, X., Li, H., He, W., Chen, J., Li, F., Zhuang, Q., Qin, B., Xu, J., Li, W., Yang, J., Gan, Y., Qin, D., Feng, S., Song, H., Yang, D., Zhang, B., Zeng, L., Lai, L., Esteban, M.A., and Pei, D. (2010). A mesenchymal-to-epithelial transition initiates and is required for the nuclear reprogramming of mouse fibroblasts. Cell Stem Cell 7, 51-63.

Li, Z., Yang, C.S., Nakashima, K., and Rana, T.M. (2011). Small RNA-mediated regulation of iPS cell generation. EMBO J 30, 823-834.

Liang, X., Zhou, D., Wei, C., Luo, H., Liu, J., Fu, R., and Cui, S. (2012). MicroRNA-34c enhances murine male germ cell apoptosis through targeting ATF1. PLoS One 7, e33861.

Lichner, Z., Pall, E., Kerekes, A., Pallinger, E., Maraghechi, P., Bosze, Z., and Gocza, E. (2011). The miR-290-295 cluster promotes pluripotency maintenance by regulating cell cycle phase distribution in mouse embryonic stem cells. Differentiation 81, 11-24.

Lim, L.P., Lau, N.C., Garrett-Engele, P., Grimson, A., Schelter, J.M., Castle, J., Bartel, D.P., Linsley, P.S., and Johnson, J.M. (2005). Microarray analysis shows that some microRNAs downregulate large numbers of target mRNAs. Nature 433, 769-773.

Lin, C.H., Jackson, A.L., Guo, J., Linsley, P.S., and Eisenman, R.N. (2009). Myc-regulated microRNAs attenuate embryonic stem cell differentiation. EMBO J 28, 3157-3170.

Lin, S.L., Chang, D.C., Lin, C.H., Ying, S.Y., Leu, D., and Wu, D.T. (2011). Regulation of somatic cell reprogramming through inducible mir-302 expression. Nucleic Acids Res $39,1054-1065$.

Liu, C.G., Calin, G.A., Meloon, B., Gamliel, N., Sevignani, C., Ferracin, M., Dumitru, C.D., Shimizu, M., Zupo, S., Dono, M., Alder, H., Bullrich, F., Negrini, M., and Croce, C.M. (2004). An oligonucleotide microchip for genome-wide microRNA profiling in human and mouse tissues. Proc Natl Acad Sci U S A 101, 9740-9744.

Liu, W.M., Pang, R.T., Chiu, P.C., Wong, B.P., Lao, K., Lee, K.F., and Yeung, W.S. (2011). Sperm-borne microRNA-34c is required for the first cleavage division in mouse. Proc Natl Acad Sci U S A 109, 490-494.

Loh, Y.H., Wu, Q., Chew, J.L., Vega, V.B., Zhang, W., Chen, X., Bourque, G., George, J., Leong, B., Liu, J., Wong, K.Y., Sung, K.W., Lee, C.W., Zhao, X.D., Chiu, K.P., Lipovich, L., Kuznetsov, V.A., Robson, P., Stanton, L.W., Wei, C.L., Ruan, Y., Lim, B., and Ng, H.H. (2006). The Oct4 and Nanog transcription network regulates pluripotency in mouse embryonic stem cells. Nat Genet 38, 431-440. 
Lujambio, A., Calin, G.A., Villanueva, A., Ropero, S., Sanchez-Cespedes, M., Blanco, D., Montuenga, L.M., Rossi, S., Nicoloso, M.S., Faller, W.J., Gallagher, W.M., Eccles, S.A., Croce, C.M., and Esteller, M. (2008). A microRNA DNA methylation signature for human cancer metastasis. Proc Natl Acad Sci U S A 105, 13556-13561.

Lujambio, A., and Esteller, M. (2009). How epigenetics can explain human metastasis: a new role for microRNAs. Cell Cycle 8, 377-382.

Luningschror, P., Stocker, B., Kaltschmidt, B., and Kaltschmidt, C. (2012). miR-290 cluster modulates pluripotency by repressing canonical NF-kappaB signaling. Stem Cells 30, 655-664.

Ma, J., Flemr, M., Stein, P., Berninger, P., Malik, R., Zavolan, M., Svoboda, P., and Schultz, R.M. (2010). MicroRNA activity is suppressed in mouse oocytes. Curr Biol 20, 265270.

Ma, J.Y., Li, M., Ge, Z.J., Luo, Y., Ou, X.H., Song, S., Tian, D., Yang, J., Zhang, B., OuYang, Y.C., Hou, Y., Liu, Z., Schatten, H., and Sun, Q.Y. (2012). Whole transcriptome analysis of the effects of type I diabetes on mouse oocytes. PLoS One 7, e41981.

Maatouk, D.M., Loveland, K.L., McManus, M.T., Moore, K., and Harfe, B.D. (2008). Dicer1 is required for differentiation of the mouse male germline. Biol Reprod 79, 696-703.

MacRae, I.J., Ma, E., Zhou, M., Robinson, C.V., and Doudna, J.A. (2008). In vitro reconstitution of the human RISC-loading complex. Proc Natl Acad Sci U S A 105, $512-517$.

Malumbres, M., Sotillo, R., Santamaria, D., Galan, J., Cerezo, A., Ortega, S., Dubus, P., and Barbacid, M. (2004). Mammalian cells cycle without the D-type cyclin-dependent kinases Cdk4 and Cdk6. Cell 118, 493-504.

Marson, A., Levine, S.S., Cole, M.F., Frampton, G.M., Brambrink, T., Johnstone, S., Guenther, M.G., Johnston, W.K., Wernig, M., Newman, J., Calabrese, J.M., Dennis, L.M., Volkert, T.L., Gupta, S., Love, J., Hannett, N., Sharp, P.A., Bartel, D.P., Jaenisch, R., and Young, R.A. (2008). Connecting microRNA genes to the core transcriptional regulatory circuitry of embryonic stem cells. Cell 134, 521-533.

Mencia, A., Modamio-Hoybjor, S., Redshaw, N., Morin, M., Mayo-Merino, F., Olavarrieta, L., Aguirre, L.A., del Castillo, I., Steel, K.P., Dalmay, T., Moreno, F., and MorenoPelayo, M.A. (2009). Mutations in the seed region of human miR-96 are responsible for nonsyndromic progressive hearing loss. Nat Genet 41, 609-613.

Meng, Y.N., Meng, L.J., Song, Y.J., Liu, M.L., and Zhang, X.J. (2011). [Small RNA molecules and regulation of spermatogenesis]. Yi Chuan 33, 9-16. 
Michlewski, G., Guil, S., Semple, C.A., and Caceres, J.F. (2008). Posttranscriptional regulation of miRNAs harboring conserved terminal loops. Mol Cell 32, 383-393.

Morin, R.D., O'Connor, M.D., Griffith, M., Kuchenbauer, F., Delaney, A., Prabhu, A.L., Zhao, Y., McDonald, H., Zeng, T., Hirst, M., Eaves, C.J., and Marra, M.A. (2008). Application of massively parallel sequencing to microRNA profiling and discovery in human embryonic stem cells. Genome Res 18, 610-621.

Murchison, E.P., Partridge, J.F., Tam, O.H., Cheloufi, S., and Hannon, G.J. (2005). Characterization of Dicer-deficient murine embryonic stem cells. Proc Natl Acad Sci U S A 102, 12135-12140.

Murchison, E.P., Stein, P., Xuan, Z., Pan, H., Zhang, M.Q., Schultz, R.M., and Hannon, G.J. (2007). Critical roles for Dicer in the female germline. Genes Dev 21, 682-693.

Nam, Y., Chen, C., Gregory, R.I., Chou, J.J., and Sliz, P. (2011). Molecular basis for interaction of let-7 microRNAs with Lin28. Cell 147, 1080-1091.

Newman, M.A., Thomson, J.M., and Hammond, S.M. (2008). Lin-28 interaction with the Let-7 precursor loop mediates regulated microRNA processing. RNA 14, 1539-1549.

Nicolas, F.E. (2011). Experimental validation of microRNA targets using a luciferase reporter system. Methods Mol Biol 732, 139-152.

Niu, Z., Goodyear, S.M., Rao, S., Wu, X., Tobias, J.W., Avarbock, M.R., and Brinster, R.L. (2011). MicroRNA-21 regulates the self-renewal of mouse spermatogonial stem cells. Proc Natl Acad Sci U S A 108, 12740-12745.

Niwa, H. (2007). How is pluripotency determined and maintained? Development 134, 635646.

O'Donnell, K.A., Wentzel, E.A., Zeller, K.I., Dang, C.V., and Mendell, J.T. (2005). c-Mycregulated microRNAs modulate E2F1 expression. Nature 435, 839-843.

Ortega, S., Prieto, I., Odajima, J., Martin, A., Dubus, P., Sotillo, R., Barbero, J.L., Malumbres, M., and Barbacid, M. (2003). Cyclin-dependent kinase 2 is essential for meiosis but not for mitotic cell division in mice. Nat Genet 35, 25-31.

Osman, A. (2012). MicroRNAs in health and disease--basic science and clinical applications. Clin Lab 58, 393-402.

Pang, A.L., Taylor, H.C., Johnson, W., Alexander, S., Chen, Y., Su, Y.A., Li, X., Ravindranath, N., Dym, M., Rennert, O.M., and Chan, W.Y. (2003). Identification of differentially expressed genes in mouse spermatogenesis. J Androl 24, 899-911.

Pangas, S.A., and Rajkovic, A. (2006). Transcriptional regulation of early oogenesis: in search of masters. Hum Reprod Update 12, 65-76. 
Park, C.Y., Choi, Y.S., and McManus, M.T. (2010). Analysis of microRNA knockouts in mice. Hum Mol Genet 19, R169-175.

Pasquinelli, A.E., Reinhart, B.J., Slack, F., Martindale, M.Q., Kuroda, M.I., Maller, B., Hayward, D.C., Ball, E.E., Degnan, B., Muller, P., Spring, J., Srinivasan, A., Fishman, M., Finnerty, J., Corbo, J., Levine, M., Leahy, P., Davidson, E., and Ruvkun, G. (2000). Conservation of the sequence and temporal expression of let-7 heterochronic regulatory RNA. Nature 408, 86-89.

Pfaff, N., Fiedler, J., Holzmann, A., Schambach, A., Moritz, T., Cantz, T., and Thum, T. (2012). miRNA screening reveals a new miRNA family stimulating iPS cell generation via regulation of Meox2. EMBO Rep 12, 1153-1159.

Plante, I., Ple, H., Landry, P., Gunaratne, P.H., and Provost, P. (2012). Modulation of microRNA Activity by Semi-microRNAs. Front Genet 3, 99.

Reinhart, B.J., Slack, F.J., Basson, M., Pasquinelli, A.E., Bettinger, J.C., Rougvie, A.E., Horvitz, H.R., and Ruvkun, G. (2000). The 21-nucleotide let-7 RNA regulates developmental timing in Caenorhabditis elegans. Nature 403, 901-906.

Reinhart, B.J., Weinstein, E.G., Rhoades, M.W., Bartel, B., and Bartel, D.P. (2002). MicroRNAs in plants. Genes Dev 16, 1616-1626.

Ro, S., Park, C., Sanders, K.M., McCarrey, J.R., and Yan, W. (2007). Cloning and expression profiling of testis-expressed microRNAs. Dev Biol 311, 592-602.

Rybak, A., Fuchs, H., Smirnova, L., Brandt, C., Pohl, E.E., Nitsch, R., and Wulczyn, F.G. (2008). A feedback loop comprising lin-28 and let-7 controls pre-let-7 maturation during neural stem-cell commitment. Nat Cell Biol 10, 987-993.

Saito, Y., Liang, G., Egger, G., Friedman, J.M., Chuang, J.C., Coetzee, G.A., and Jones, P.A. (2006). Specific activation of microRNA-127 with downregulation of the protooncogene BCL6 by chromatin-modifying drugs in human cancer cells. Cancer Cell 9, 435-443.

Sakamoto, S., Aoki, K., Higuchi, T., Todaka, H., Morisawa, K., Tamaki, N., Hatano, E., Fukushima, A., Taniguchi, T., and Agata, Y. (2009). The NF90-NF45 complex functions as a negative regulator in the microRNA processing pathway. Mol Cell Biol 29, 3754-3769.

Schwarz, D.S., Hutvagner, G., Du, T., Xu, Z., Aronin, N., and Zamore, P.D. (2003). Asymmetry in the assembly of the RNAi enzyme complex. Cell 115, 199-208.

Sinkkonen, L., Hugenschmidt, T., Berninger, P., Gaidatzis, D., Mohn, F., Artus-Revel, C.G., Zavolan, M., Svoboda, P., and Filipowicz, W. (2008). MicroRNAs control de novo 
DNA methylation through regulation of transcriptional repressors in mouse embryonic stem cells. Nat Struct Mol Biol 15, 259-267.

Smorag, L., Zheng, Y., Nolte, J., Zechner, U., Engel, W., and Pantakani, D.V. (2012). MicroRNA signature in various cell types of mouse spermatogenesis: Evidence for stage-specifically expressed miRNA-221, -203, and -34b-5p mediated spermatogenesis regulation. Biol Cell.

Song, R., Ro, S., Michaels, J.D., Park, C., McCarrey, J.R., and Yan, W. (2009). Many Xlinked microRNAs escape meiotic sex chromosome inactivation. Nat Genet 41, 488493.

Stefani, G., and Slack, F.J. (2008). Small non-coding RNAs in animal development. Nat Rev Mol Cell Biol 9, 219-230.

Suh, M.R., Lee, Y., Kim, J.Y., Kim, S.K., Moon, S.H., Lee, J.Y., Cha, K.Y., Chung, H.M., Yoon, H.S., Moon, S.Y., Kim, V.N., and Kim, K.S. (2004). Human embryonic stem cells express a unique set of microRNAs. Dev Biol 270, 488-498.

Suh, N., Baehner, L., Moltzahn, F., Melton, C., Shenoy, A., Chen, J., and Blelloch, R. (2010). MicroRNA function is globally suppressed in mouse oocytes and early embryos. Curr Biol 20, 271-277.

Suzuki, H.I., Yamagata, K., Sugimoto, K., Iwamoto, T., Kato, S., and Miyazono, K. (2009). Modulation of microRNA processing by p53. Nature 460, 529-533.

Tabara, H., Yigit, E., Siomi, H., and Mello, C.C. (2002). The dsRNA binding protein RDE-4 interacts with RDE-1, DCR-1, and a DExH-box helicase to direct RNAi in C. elegans. Cell 109, 861-871.

Takahashi, K., Tanabe, K., Ohnuki, M., Narita, M., Ichisaka, T., Tomoda, K., and Yamanaka, S. (2007). Induction of pluripotent stem cells from adult human fibroblasts by defined factors. Cell 131, 861-872.

Takahashi, K., and Yamanaka, S. (2006). Induction of pluripotent stem cells from mouse embryonic and adult fibroblast cultures by defined factors. Cell 126, 663-676.

Tam, O.H., Aravin, A.A., Stein, P., Girard, A., Murchison, E.P., Cheloufi, S., Hodges, E., Anger, M., Sachidanandam, R., Schultz, R.M., and Hannon, G.J. (2008). Pseudogenederived small interfering RNAs regulate gene expression in mouse oocytes. Nature 453, 534-538.

Tang, F., Kaneda, M., O'Carroll, D., Hajkova, P., Barton, S.C., Sun, Y.A., Lee, C., Tarakhovsky, A., Lao, K., and Surani, M.A. (2007). Maternal microRNAs are essential for mouse zygotic development. Genes Dev 21, 644-648. 
ten Berge, D., Koole, W., Fuerer, C., Fish, M., Eroglu, E., and Nusse, R. (2008). Wnt signaling mediates self-organization and axis formation in embryoid bodies. Cell Stem Cell 3, 508-518.

Tominaga, Y., Li, C., Wang, R.H., and Deng, C.X. (2006). Murine Wee1 plays a critical role in cell cycle regulation and pre-implantation stages of embryonic development. Int $\mathbf{J}$ Biol Sci 2, 161-170.

Trabucchi, M., Briata, P., Garcia-Mayoral, M., Haase, A.D., Filipowicz, W., Ramos, A., Gherzi, R., and Rosenfeld, M.G. (2009). The RNA-binding protein KSRP promotes the biogenesis of a subset of microRNAs. Nature 459, 1010-1014.

Viswanathan, S.R., Daley, G.Q., and Gregory, R.I. (2008). Selective blockade of microRNA processing by Lin28. Science 320, 97-100.

Wang, Y., Baskerville, S., Shenoy, A., Babiarz, J.E., Baehner, L., and Blelloch, R. (2008). Embryonic stem cell-specific microRNAs regulate the G1-S transition and promote rapid proliferation. Nat Genet 40, 1478-1483.

Wang, Y., Medvid, R., Melton, C., Jaenisch, R., and Blelloch, R. (2007). DGCR8 is essential for microRNA biogenesis and silencing of embryonic stem cell self-renewal. Nat Genet 39, 380-385.

Watanabe, T., Totoki, Y., Toyoda, A., Kaneda, M., Kuramochi-Miyagawa, S., Obata, Y., Chiba, H., Kohara, Y., Kono, T., Nakano, T., Surani, M.A., Sakaki, Y., and Sasaki, H. (2008). Endogenous siRNAs from naturally formed dsRNAs regulate transcripts in mouse oocytes. Nature 453, 539-543.

White, J., and Dalton, S. (2005). Cell cycle control of embryonic stem cells. Stem Cell Rev 1, 131-138.

Wienholds, E., Koudijs, M.J., van Eeden, F.J., Cuppen, E., and Plasterk, R.H. (2003). The microRNA-producing enzyme Dicer1 is essential for zebrafish development. Nat Genet $35,217-218$.

Wightman, B., Burglin, T.R., Gatto, J., Arasu, P., and Ruvkun, G. (1991). Negative regulatory sequences in the lin-14 3'-untranslated region are necessary to generate a temporal switch during Caenorhabditis elegans development. Genes Dev 5, 1813-1824.

Wightman, B., Ha, I., and Ruvkun, G. (1993). Posttranscriptional regulation of the heterochronic gene lin-14 by lin-4 mediates temporal pattern formation in C. elegans. Cell 75, 855-862. 
Winter, J., Jung, S., Keller, S., Gregory, R.I., and Diederichs, S. (2009). Many roads to maturity: microRNA biogenesis pathways and their regulation. Nat Cell Biol 11, 228234.

Wu, Q., Song, R., Ortogero, N., Zheng, H., Evanoff, R., Small, C.L., Griswold, M.D., Namekawa, S.H., Royo, H., Turner, J.M., and Yan, W. (2012). The RNase III Enzyme DROSHA Is Essential for MicroRNA Production and Spermatogenesis. J Biol Chem 287, 25173-25190.

Wu, S.M., Baxendale, V., Chen, Y., Pang, A.L., Stitely, T., Munson, P.J., Leung, M.Y., Ravindranath, N., Dym, M., Rennert, O.M., and Chan, W.Y. (2004). Analysis of mouse germ-cell transcriptome at different stages of spermatogenesis by SAGE: biological significance. Genomics 84, 971-981.

Xia, W., Cao, G., and Shao, N. (2009). Progress in miRNA target prediction and identification. Sci China C Life Sci 52, 1123-1130.

Yamagata, K., Fujiyama, S., Ito, S., Ueda, T., Murata, T., Naitou, M., Takeyama, K., Minami, Y., O'Malley, B.W., and Kato, S. (2009). Maturation of microRNA is hormonally regulated by a nuclear receptor. Mol Cell 36, 340-347.

Yan, N., Lu, Y., Sun, H., Tao, D., Zhang, S., Liu, W., and Ma, Y. (2007). A microarray for microRNA profiling in mouse testis tissues. Reproduction 134, 73-79.

Yi, R., Qin, Y., Macara, I.G., and Cullen, B.R. (2003). Exportin-5 mediates the nuclear export of pre-microRNAs and short hairpin RNAs. Genes Dev 17, 3011-3016.

Yoshinaga, K., Nishikawa, S., Ogawa, M., Hayashi, S., Kunisada, T., and Fujimoto, T. (1991). Role of c-kit in mouse spermatogenesis: identification of spermatogonia as a specific site of c-kit expression and function. Development 113, 689-699.

Yu, J., Vodyanik, M.A., Smuga-Otto, K., Antosiewicz-Bourget, J., Frane, J.L., Tian, S., Nie, J., Jonsdottir, G.A., Ruotti, V., Stewart, R., Slukvin, II, and Thomson, J.A. (2007). Induced pluripotent stem cell lines derived from human somatic cells. Science 318, 1917-1920.

Yu, Z., Guo, R., Ge, Y., Ma, J., Guan, J., Li, S., Sun, X., Xue, S., and Han, D. (2003). Gene expression profiles in different stages of mouse spermatogenic cells during spermatogenesis. Biol Reprod 69, 37-47.

Yu, Z., Raabe, T., and Hecht, N.B. (2005). MicroRNA Mirn122a reduces expression of the posttranscriptionally regulated germ cell transition protein 2 (Tnp2) messenger RNA (mRNA) by mRNA cleavage. Biol Reprod 73, 427-433. 
Zhang, N., Liu, J., Ding, X., Aikhionbare, F., Jin, C., and Yao, X. (2007). FBXL5 interacts with p150Glued and regulates its ubiquitination. Biochem Biophys Res Commun 359, 34-39.

Zhao, M., Shirley, C.R., Yu, Y.E., Mohapatra, B., Zhang, Y., Unni, E., Deng, J.M., Arango, N.A., Terry, N.H., Weil, M.M., Russell, L.D., Behringer, R.R., and Meistrich, M.L. (2001). Targeted disruption of the transition protein 2 gene affects sperm chromatin structure and reduces fertility in mice. Mol Cell Biol 21, 7243-7255.

Zovoilis, A., Nolte, J., Drusenheimer, N., Zechner, U., Hada, H., Guan, K., Hasenfuss, G., Nayernia, K., and Engel, W. (2008). Multipotent adult germline stem cells and embryonic stem cells have similar microRNA profiles. Mol Hum Reprod 14, 521-529.

Zovoilis, A., Pantazi, A., Smorag, L., Opitz, L., Riester, G.S., Wolf, M., Zechner, U., Holubowska, A., Stewart, C.L., and Engel, W. (2010). Embryonic stem cell-related miRNAs are involved in differentiation of pluripotent cells originating from the germ line. Mol Hum Reprod 16, 793-803.

Zovoilis, A., Smorag, L., Pantazi, A., and Engel, W. (2009). Members of the miR-290 cluster modulate in vitro differentiation of mouse embryonic stem cells. Differentiation 78, 6978. 


\section{Abbreviations}

${ }^{\circ} \mathrm{C}$

degree Celsius

Ago-2

Argonaute-2

AP

Alkaline phosphatase

bFGF

Basic fibroblast growth factor

Bmp-4

Bone morphogenetic protein 4

Boll

Boule-like

bp

base pair

Cdk6

Cyclin-dependent kinase 6

cDNA

complementary DNA

ChIP

Chromatin Immunoprecipitation

DAPI

Diamidino-2-phenylindole dihydrochloride

Dazl

Deleted in azoospermia-like

Dgcr8

DiGeorge syndrome critical region gene 8

Dkk1

Dickkopf-related protein 1

DNA

Deoxyribonucleic acid

dpc

day post coitum

dpp

day postpartum

Dppa3

Developmental pluripotency associated 3

DsRed

Discosoma sp. Red Fluorescent Protein

dsRNA

double stranded RNA

dTg

double transgenic

ECCs

Embryonic Carcinoma Cells

EGCs

Embryonic Germ Cells

EGF

Epidermal growth factor

EGFP

Enhanced Green Fluorescent Protein

ESCs

Embryonic Stem Cells

FACS

Fluorescence-Activated Cell Sorting

FCS

Fetal Calf Serum

Fgf8

Fibroblast growth factor 8

FL

feeder layer

Fndc3a

Fibronectin type III domain containing 3A 
GDNF

GO

gPSs

GSK3 $\beta$

hnRNP A1

HRP

ICR

Igf2r

$\mathrm{kb}$

$\mathrm{kDa}$

Klf4

$\mathrm{KO}$

KSRP

LIF

LPR5/6

M

MACS

maGSCs

MEFs

Meg3

mGSCs

miRISC

miRNA or miR

mRNA

MSCI

ncRNA

NF45

NF90

nt

Oct4

OG-2

ORF

Ovol1

PAGE
Glial cell-derived neurotrophic factor

Gene Ontology

germline-derived Pluripotent Stem Cells

Glycogen synthase kinase- 3 beta

Heterogeneous nuclear ribonucleoprotein A1

Horseradish peroxidase

Imprinting Control Regions

Insulin-like growth factor 2 receptor

kilobase pairs

kilo Dalton

Kruppel-like factors 4

Knock-out

KH-type splicing regulatory protein

Leukemia Inhibitory Factor

Lipoprotein receptor-related 5/6

Molarity

Magnetic Activated Cell Sorting

multipotent adult Germline Stem Cells

Mouse embryonic fibroblasts

Maternally expressed 3

multipotent Germline Stem Cells

microRNA Induced Silencing Complex

microRNA

messenger RNA

Meiotic sex chromosome inactivation

non-coding RNA

Nuclear factor 45

Nuclear factor 90

nucleotide

Octamer-binding transcription factor 4

Oct4/EGFP

Open reading frame

Ovo-like 1

Polyacrylamide Gel Electrophoresis 
Pasha

PCR

PGCs

Piwil-2

Plzf

PoM

pre-miRNA

pri-miRNA

PrM

Prm1

qRT-PCR

RA

Rbl2

$\mathrm{Rbm} 44$

RDE-4

RNA Pol

RNA

Rnf-17

Rpl13

Rsbn1

R-Smads

RT-PCR

Sall4

SD

Sdha

SDS

siRNA

smiRNA

Snrpn

Sox 2

SSCs

Stag3

Stra8

stRNA
Partner of Drosha

Polymerase Chain Reaction

Primordial Germ Cells

Piwi-like 2

Promyelocytic leukaemia zinc finger

post-meiotic

precursor microRNA

primary microRNA

pre-meiotic

Protamine 1

quantitative RT-PCR

Retinoic acid

Retinoblastoma-like protein 2

RNA binding motif protein 44

RNAi Defective-4

RNA polymerase

ribonucleic acid

Ring finger protein 17

Ribosomal protein L13

Round spermatid basic protein 1

receptor-regulated Smads

Reverse Transcription PCR

Sal-like protein 4

standard deviation

Succinate dehydrogenase complex, subunit A

Sodium Dodecylsulfate

small interfering RNA

semiRNA

Small nuclear ribonucleoprotein-associated protein $\mathrm{N}$

Sex determining region Y-box 2

Spermatogonial stem cells

Stromal antigen 3

Stimulated by retinoic acid gene 8

Small temporal RNA 
Sycp3

TBST

Tnp2

Tox

Tp2

TRBP

UTR

$\beta-\mathrm{Gal}$

$\mu \mathrm{m}$
Synaptonemal complex protein 3

Tris-Buffered Saline and Tween 20

Transition protein 2

Thymocyte selection-associated high mobility group box

Transition protein 2

HIV-1 TAR RNA binding protein

Untranslated Region

$\beta$-Galactosidase

micrometer 


\section{Acknowledgments}

I wish to express my sincere gratitude to Prof. Dr. med. Dr. h. c. Wolfgang Engel for his excellent guidance and many insightful conversations during the development of ideas in this thesis work. I am honored to have such a great personality as my mentor and I thank him for helpful comments, continuous support, and fruitful scientific discussions/suggestions during my whole $\mathrm{PhD}$ period.

I would like to express my deep sense of gratitude and sincere thanks to my supervisor, Dr. Krishna Pantakani, whose expertise, understanding and patience, added considerably to my $\mathrm{PhD}$ experience. I appreciate his vast knowledge, personal attention, keen interest, and expert guidance during the entire course of my $\mathrm{PhD}$ work and assistance in writing this thesis.

My sincere thanks to the members of the thesis committee; Prof. Dr. Sigrid HoyerFender, Prof. Dr. Michael Kessel, Prof. Dr. Ahmed Mansouri, Prof. Dr. Tomas Pieler and Prof. Dr. Peter Schu for taking time out from their busy schedule to serve as my examiners and for their critical reading of my thesis.

I would like to thank Dr. Jessica Nolte for providing study materials as well as for the constructive critics and helpful advises throughout my study.

No words can truly express my deepest gratitude to my lovely wife Joanna, who helped me and shared my ups and downs and made my stay in Goettingen a wonderful memory.

I am thankful to my lab mates Xiaoying and Xingbo and all my institute colleagues for their friendship, discussions, advices, help and fantastic working environment.

Special acknowledgments and thanks to my parents and all my family members for encouragement and the moral support they provided me. 


\section{Curriculum Vitae}

\section{Personal details:}

Name:

Date of birth:

Place of birth:

Address:

E-mail:

\section{Education:}

Sep. 1991-Jun. 1999

Sep. 1999-Jun. 2003

Oct. 2003-Jul. 2008

Jan. 2008-Dec. 2008

Since May 2009
Lukasz Smorag

07.01 .1984

Krapkowice (Poland)

Fichtenweg 18, 37077 Göttingen

1smorag@gwdg.de

Primary School in Krapkowice (Poland)

Secondary School in Opole (Poland)

Diploma thesis: "Efficiency of IFV in mouse inbred mouse strains differ in Y chromosome"

Department of Genetics and the Biology of Reproduction, Jagiellonian University, Krakow, Poland

Supervisor: Prof. Dr. hab. Jozefa Styrna

One-year practice at the Institute of Human Genetics, GeorgAugust-University, Göttingen, Germany

Supervisor: Prof. Dr. Dr. h. c. Wolfgang Engel

Ph.D. thesis: "miRNA functions in pluripotency and spermatogenesis.

Institute of Human Genetics, Georg-August-University, Göttingen, Germany

Supervisor: Prof. Dr. Dr. h. c. Wolfgang Engel 


\section{List of publications}

1. Zovoilis A, Smorag L, Pantazi A, Engel W: Members of the miR-290 cluster modulate in vitro differentiation of mouse embryonic stem cells. Differentiation 2009, 78(2-3):69-78.

2. Zovoilis A, Pantazi A, Smorag L, Opitz L, Riester GS, Wolf M, Zechner U, Holubowska A, Stewart CL, Engel W: Embryonic stem cell-related miRNAs are involved in differentiation of pluripotent cells originating from the germ line. Mol Hum Reprod 2010, 16(11):793-803.

3. Smorag L, Zheng Y, Nolte J, Zechner U, Engel W, Pantakani DV: MicroRNA signature in various cell types of mouse spermatogenesis: Evidence for stagespecifically expressed miRNA-221, -203, and -34b-5p mediated spermatogenesis regulation. Biol Cell 2012 Nov;104(11):677-92.

\section{List of manuscripts in submission stage}

1 Xu X, NakamuraT, Smorag L, Dressel R, Fitzner A, Linke M, Nolte J, Zechner U, Engel W, Pantakani DV. Dppa3 binds to the IG-DMR of the Dlk1-Dio3 imprinting cluster and prevents its imprinting loss during the iPS cells generation. (Manuscipt under review) 